OAK RIDGE

NATIONAL LABORATORY

ORNL/TM-2013/00

MANAGED BY UT-BATTELLE

FOR THE DEPARTMENT OF ENERGY

\title{
US Woody Crop Yield Potential Database Documentation with Referenced Yield Summary Tables
}

\section{October 25, 2013}

Prepared by

Lynn Wright

Biomass Feedstock Consultant

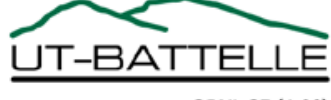

ORNL-27 (4-00) 


\title{
DOCUMENT AVAILABILITY
}

Reports produced after January 1, 1996, are generally available free via US Department of Energy (DOE) SciTech Connect.

Website http://www.osti.gov/scitech/

Reports produced before January 1, 1996, may be purchased by members of the public from the following source:

\author{
National Technical Information Service \\ 5285 Port Royal Road \\ Springfield, VA 22161 \\ Telephone 703-605-6000 (1-800-553-6847) \\ TDD 703-487-4639 \\ Fax 703-605-6900 \\ E-mail info@ntis.gov \\ Website http://www.ntis.gov/support/ordernowabout.htm
}

Reports are available to DOE employees, DOE contractors, Energy Technology Data Exchange representatives, and International Nuclear Information System representatives from the following source:

Office of Scientific and Technical Information

PO Box 62

Oak Ridge, TN 37831

Telephone 865-576-8401

Fax 865-576-5728

E-mail reports@osti.gov

Website http://www.osti.gov/contact.html

This report was prepared as an account of work sponsored by an agency of the United States Government. Neither the United States Government nor any agency thereof, nor any of their employees, makes any warranty, express or implied, or assumes any legal liability or responsibility for the accuracy, completeness, or usefulness of any information, apparatus, product, or process disclosed, or represents that its use would not infringe privately owned rights. Reference herein to any specific commercial product, process, or service by trade name, trademark, manufacturer, or otherwise, does not necessarily constitute or imply its endorsement, recommendation, or favoring by the United States Government or any agency thereof. The views and opinions of authors expressed herein do not necessarily state or reflect those of the United States Government or any agency thereof. 
Environmental Sciences Division

\title{
US WOODY CROP YIELD POTENTIAL DATABASE DOCUMENTATION WITH REFERENCED YIELD SUMMARY TABLES
}

\author{
Lynn Wright
}

October 25, 2013

\author{
Prepared by \\ OAK RIDGE NATIONAL LABORATORY \\ Oak Ridge, Tennessee 37831-6283 \\ managed by \\ UT-BATTELLE, LLC \\ for the \\ US DEPARTMENT OF ENERGY \\ under contract DE-AC05-00OR22725
}





\section{CONTENTS}

\section{Page}

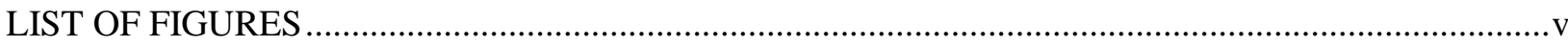

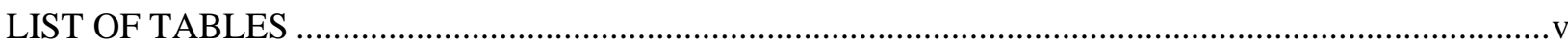

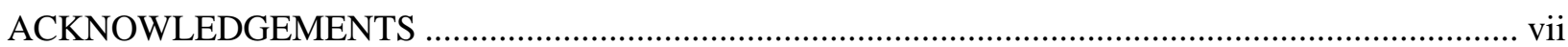

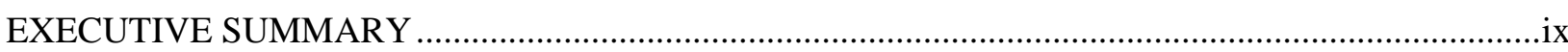

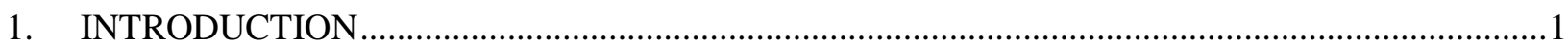

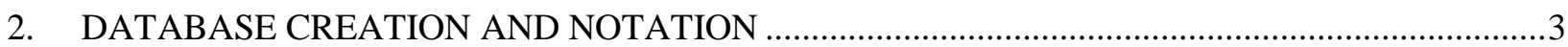

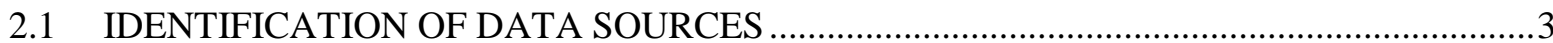

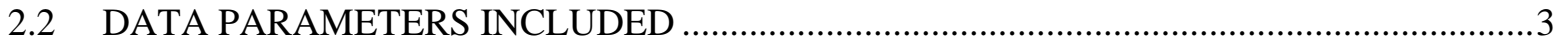

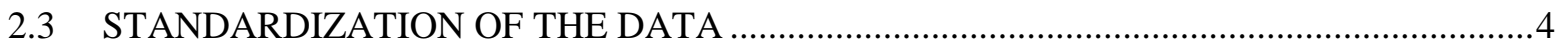

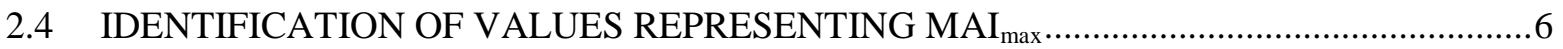

2.5 IDENTIFICATION OF VALUES SUITABLE FOR YIELD POTENTIAL

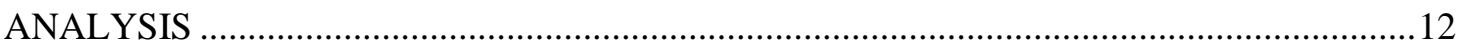

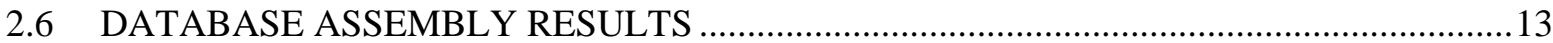

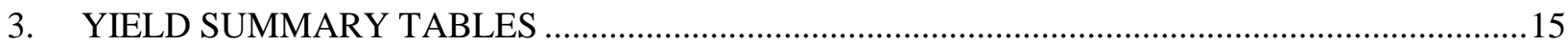

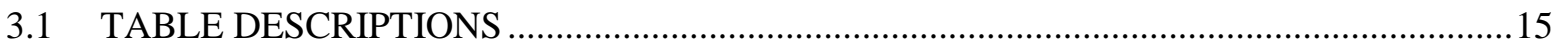

3.2 BRIEF SUMMARY OF TREATMENT EFFECTS ON WOODY CROP YIELDS................21

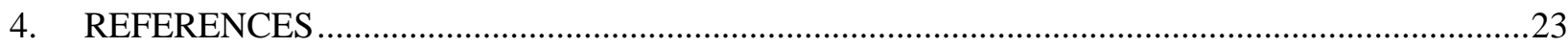

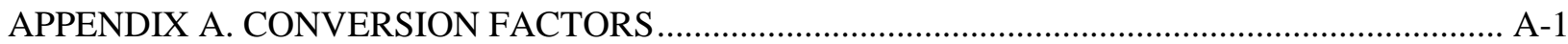

APPENDIX B. NUTRIENT APPLICATION RATE STANDARDIZATION ….....................................

APPENDIX C. EXPLANATION OF WHY SPACING AND DENSITY VALUES WERE

NOT TOTALLY STANDARDIZED ACROSS EXPERIMENTS................................................... 



\section{LIST OF FIGURES}

Figure

1 Example of a relatively easy to interpret hybrid poplar growth pattern in a stand planted at about 10,000 trees ha ${ }^{-1}$.

2 Example of a more confusing hybrid poplar growth pattern in a stand planted at about 40,000 trees ha ${ }^{-1}$.

3 Example of an incomplete growth data set for hybrid poplars planted at 1075 trees $\mathrm{ha}^{-1}$...................8

4 Example of an atypical growth pattern of hybrid poplars planted at 1075 trees ha ${ }^{-1}$...........................8

5 Annually harvested willow coppice trials planted at more than 400,000 trees $\mathrm{ha}^{-1}$ and fertilized.

6 Annually harvested willow coppice trials planted at more than 400,000 trees ha ${ }^{-1}$ with no fertilization.

7 Example of mean annual increment growth in an intensively cultured loblolly pine stand planted at 2,990 trees ha ${ }^{-1}$ with measurements taken only in years 2, 3, and 5 .

8 Example of growth in an intensively cultured loblolly pine growth pattern planted at 1,660 trees $\mathrm{ha}^{-1}$.

9 Example of growth in an intensively cultured loblolly pine stand planted at 1,070 trees ha ${ }^{-1}$

\section{LIST OF TABLES}

Table

1 Maximum mean annual yields from published growth curves of willow (Salix dasyclados) and hybrid poplar (Populus) in high density small plot silviculture and clone trials in the Northeast grouped by culture intensity level

2 Maximum mean annual yields of poplars (Populus hybrids and Populus detoides), silver maple (Acer saccharinum), alder (Alnus glutinosa) and black locust (Robinia pseudoacacia) in small-plot silvicultural and clone trials in the North Central and Mid-west United States grouped by culture intensity level

3 mean annual yields (or harvest yields) from published growth curves of cottonwood (Populus trichocarpa) and poplar (Populus) hybrids in small plot silvicultural and clone trials in the Pacific Northwest grouped by culture intensity level

4 Maximum mean annual yields (or final measurements) from published growth curves of hardwoods (sweetgum, Liquidambar styraciflua; sycamore, Platanus occidentalis; Eucalyptus, Eucalyptus grandis and Eucalyptus amplifolia; water-willow oak, Quercus sp.) in small plot silvicultural trials evaluated in the southern United States grouped by culture intensity level

5 Near maximum mean annual yields (or final measurements) from published growth curves of loblolly pine (Pinus taeda L.) evaluated in southeastern small plot silvicultural trials grouped by culture intensity level. 



\section{ACKNOWLEDGEMENTS}

Research sponsored by the U.S. Department of Energy - Office of energy Efficiency and Renewable Energy, Bioenergy Technologies Office. UT Battelle, LLC manages the Oak Ridge National Laboratory for the U.S. Department of Energy under contract DE-05-00OR22725 with UT-Battelle, LLC.

The author wishes to thank the managers and staff of Oak Ridge National Laboratory's Environmental Sciences Division for facilitating the continuation of my work on summarizing woody crop yield data that began in 1982 when I first joined the Short Rotation Woody Crops Program (later a part of the Biofuels Feedstock Development Program) as a subcontract manager for woody crops research. Many Environmental Sciences Division staff contributed to managing woody crop research and to collecting and maintaining the woody crop feedstock reference collections that made development of the Woody Crop Yield Potential (WCYP) database possible.

The author wishes to thank many researchers and students from many different academic, industrial and U.S. Forest Service institutions who have participated in research on short-rotation woody crops over the past 40 years and particularly those that have published their data on biomass dry weight yields in the form of growth curves or tables of annual growth. It is hoped that those efforts will continue well into the future so that a much larger database of information on woody crop yields can be assembled and made publically available. 



\section{EXECUTIVE SUMMARY}

A woody crop yield potential (WCYP) database was created containing yield results with as much associated information as was available concerning the sites, soils, and experimental treatments.

The database summarizes a very broad set of old and new standing biomass data from plantation-grown hardwoods and softwoods established under a wide range of conditions across the United States and Canada. The WCYP database, together with this document, is being published to disseminate information on what is available in the literature with respect to yield evaluations and to inform people that not all yield data in the open literature are suitable for evaluation of "potential” regional yields. It has also been presented with the hope that much more information will be collected and added to the WCYP database.

The current set of data in the WCYP database is derived from 41 unique reference sources describing 79 experiments in the United States or southern Canada with a total of 473 different treatments. The database contains several worksheets. The worksheet that reports the complete yield curves contains roughly 1,660 rows of data and 81 columns of parameters reporting yields and associated treatment factors. Separate worksheets, linked by the source publication author and year, describe the sites and soils associated with each experiment; another separate worksheet assembles only the final yields deemed appropriate for yield potential analysis. There are additional worksheets with conversion factors relevant to the database and notes pertaining to decisions made regarding organization of the data. This technical manuscript describes how the information was assembled to create the WCYP database that is simultaneously being published on the US Department of Energy (DOE) Bioenergy Knowledge Discovery Framework website maintained by Oak Ridge National Laboratory (ORNL). A summary table with links to all worksheets in the database can be found at the web address

https://www.bioenergykdf.net/WCYP.

Of the 473 experimental treatments included in the 79 experiments described in the WCYP database, documentation for only about 170 of the treatments provided sufficient growth pattern information for verifying that the measurements had included yield data deemed to be at or near the age of maximum mean annual increment ( $\mathrm{MAI}_{\max }$ ). Thus only $36 \%$ of the treatments in the studies on woody crop growth curves were followed long enough to actually obtain the maximum average yield obtainable with the specific treatment. This is to be expected because once the maximum yields of the best treatment options are identified in an experiment, there is marginal value in continuing to measure the less than optimal treatment conditions of that experiment.

Fourteen of the reference sources used for development of the WCYP database did not report sufficient growth pattern information to verify the point of $\mathrm{MAI}_{\max }$ in any of the treatments evaluated. The yield results from the incomplete studies were nevertheless included for one or more of the following reasons: (1) the results provided useful or interesting site or treatment comparisons, (2) the authors (of the data sources) believed the stands were at an appropriate harvest age for the chosen planting density, or (3) the experiments are continuing and additional data may become available.

Of the 170 treatments verified to be at or near $\mathrm{MAI}_{\max }$, only 101 were considered useful for evaluating yield potential as some of the treatments were controls or low culture intensity treatments that did not produce high yields. However, some reported mean annual increment values, while not verifiable based on growth curves, were sufficiently high to be considered of value in assessing yield potential. Thus the final conclusion was that 123 yield values (rows in the database) were of value for use in woody crop yield potential studies. This provides relatively few data points for performing the types of statistical analyses that have been done for switchgrass. 
Nearly all data sets included in the database, many of which resulted from DOE Biomass Program funding, were found in publically available information sources. The majority of those were peerreviewed literature sources. In some cases, non-peer-reviewed proceedings, papers, presentations, and student theses or dissertations also served as sources of yield data and as sources for some of the experimental details associated with the yield data. While electronically available, such sources cannot be easily found without intense and very specific searches on the Internet. In some cases, use of multiple papers from the same research institution were required to obtained the desired level of detail on the experimental sites and methods. In a few cases, some experimental details were not found in public reports but were gleaned from the collection of unpublished biomass research subcontractor reports housed at ORNL. To the extent possible, those sources are being digitized and made available through ORNL websites

This publication also includes tables with selected yield values from the database as a means of providing a condensed summary of a large portion of the database. The tables purposely show high, medium, and low mean annual yields of hardwoods within four regions of the United States (the Northeast, Southeast, North Central/Midwest, and Pacific Northwest) and pine yields in the Southeast, using culture intensity as the grouping factor. The Southeast pine yields were included because the amount of information on Southeast hardwoods is limited and pines are an important biomass resource in the Southeast.

No effort was made in this publication to present any statistical analysis of the yield data as a function of culture intensity or region because it was determined that the data were too limited for useful statistical analysis. The tables do show, however, that yields can sometimes be very high (> $\left.20 \mathrm{Mg} \mathrm{ha}^{-1} \mathrm{yr}^{-1}\right)$ under high intensity cultural treatments or when selected clones are matched to good site conditions. While we cannot yet adequately predict potential yield level averages across the United States, it is the belief of this author that with careful selection of clones or varieties and appropriate management practices, yields of at least $15 \mathrm{Mg} \mathrm{ha}^{-1} \mathrm{yr}^{-1}$ can be obtained with woody crops in most crop growing regions of the United States. 


\section{INTRODUCTION}

To document the basis for the biomass yield assumptions being used in biomass resource analysis studies, an effort was initiated to identify sources of information on woody crop yields and to create a woody crop yield potential (WCYP) database that can be used by others to conduct further analysis on woody crop yields in the United States and Canada. The primary goal was to identity which data from the many publications available on woody crops accurately represent the yield potential of woody crop stands. The yield potential is not derived from an average of existing experimental and commercial stand yields, but rather focuses on finding those situations where genotypes and cultural treatments have come close to being optimized for sites and climates and where the stand has been grown to optimal harvest age (generally identified as the year when the mean value of annual growth is maximized). This is needed to facilitate yield mapping activities and comparisons on a dry-weight basis with yields of annual and perennial herbaceous crops that are harvested annually. Thus a literature search was initiated to find such data and incorporate it into a WCYP database. This database differs from a summary of all yields from all experimental trials since experimental trials that clearly did not use good silvicultural practices or clones that did not meet at least average expectations were excluded.

The task of finding woody crop mean annual yield data at or near the age of optimal harvest in the United States proved to be challenging even though a large amount of research has been performed in the United States on woody crops. A similar effort to collect data on perennial grasses provided much more data. The reason is that each year of growth of a perennial grass (beyond the first year or two of establishment) provides a data point on harvested yields that can be useful for evaluation of biomass resources, whereas with woody crops grown for multiple years, only the annualized yield at the expected harvest age or yield at the point of the stand's biological maximum mean annual increment ( $\left.\mathrm{MAI}_{\max }\right)$ are useful data points for comparison with annually harvested biomass crops. The expected harvest age (usually based on economic analysis) and the biological maximum growth rate of woody crop stands are often the same, but may differ under various economic assumptions. Thus this analysis is limited to identifying the biological MAI $I_{\max }$.

While silvicultural studies that compare the effects of cultural treatments and genotypes on productivity at a given site are not uncommon, continued measurement of the experimental stands past the point of $\mathrm{MAI}_{\max }$ are relatively rare due both to funding constraints and lack of interest once the relative effects of treatments on productivity rates are identified. For example, a 2008 effort to identify publications within the previous 10 years on poplar and willow growth, production, and biomass yield generated 67 papers worldwide with experimental results documenting some type of incremental growth data (height; diameter; basal area; stem biomass; or, preferably, total aboveground biomass, expressed as tons per acre or megagrams per hectare). Only 42 of the experiments described were conducted in the United States or Canada, and only 21 of those provided enough detail to calculate either cumulative, mean annual, or incremental annual total aboveground growth over several years of growth. Of the studies with adequate detail, only 11 provided data that met the goal of reporting woody crop yields in a way that verified the yields were at or near $\mathrm{MAI}_{\max }$. The yield database was enlarged by broadening the search of published literature to include a broader range of species and a longer time period and by including unpublished reports and presentations collected by staff at Oak Ridge National Laboratory (ORNL).

Additional objectives of this database project were (1) to find and document the highest reported yields of any woody crop species considered suitable for bioenergy production whether or not the yield curves could be verified to have achieved $\mathrm{MAI}_{\max }$ and (2) to include data from all major regions of the United States and from all woody species that have received attention as potential bioenergy crops.

The focus of this document is to describe how the WCYP database was created and the type and range of data included in the database. Several tables with yield data are included in this paper, not for the purpose 
of comprehensive analysis, but rather to demonstrate potential insights that can be gleaned from a study of the WCYP database. The tables include information on key factors affecting the average annual yield and economics of growing woody crops for energy. The tables do not attempt to include all of the values in the WCYP database that are considered useful for evaluating woody crop yield potential or for assessing the effects of treatment factors. The tables do provide insight to the type of information available in the WCYP database. The complete WCYP database can be viewed or downloaded from the US Department of Energy (DOE) Bioenergy Knowledge Discovery Framework website maintained by ORNL by navigating to the web address https://www.bioenergykdf.net/WCYP . 


\section{DATABASE CREATION AND NOTATION}

\subsection{IDENTIFICATION OF DATA SOURCES}

The project documented in this report began in 2008 when online search engines were used to identify recent papers (defined as those published after about 1998) using the search terms "poplar" or "willow" together with "growth," "production,” or "yield.” As mentioned previously, that process resulted in many papers being identified but only 11 publications with sufficient information for building the woody crops maximum yield database. Expansion of the online search to include the general terms "woody crops" and "biomass yields," without limiting the species, identified several recently published papers on intensive culture experiments on southern pines, sweetgum, eucalyptus, and sycamore in the Southeast. Inclusion of the southeastern silvicultural research on pines and hardwoods greatly increased the value of the WCYP database by allowing inclusion of a wider range of locations and site types. The literature search was further expanded to an internal bibliographic database (and associated physical library) originally created by the ORNL Biomass Feedstock Development Program that included older published papers, conference proceedings, web-available presentations, and subcontractor reports to the DOE Biomass Program managed at ORNL.

The preferred information sources (whether recent or older) were those that reported total aboveground biomass results in tables or graphs on an annual basis for each experimental condition. Publications that provided good information on the site and experimental conditions were greatly preferred. When necessary, multiple sources of information (including calls to authors and unpublished information) were used to make the supporting information as complete as possible. A few publications that provided excellent descriptions of the experimental conditions but only provided yield data from the final year of observation of the tree stands were included (as long as that final year was believed to represent a reasonable harvest age). While data presented in tables was most easily accessible, data provided in the form of graphs was translated to numbers by using a plot digitizer. For very high density single stem or multi-stemmed "coppiced" stands (e.g. 10,000 to 400,000 stems per hectare), a minimum of 3 years of annual growth results (annual harvests or estimates of cumulative, incremental, or mean growth) were required for consideration for inclusion in the data set. The adequate number of years of observation varied between 4 and 12 years as planting density (or coppice stem density) decreased from 10,000 to less than 1,000 trees or stems per hectare.

\subsection{DATA PARAMETERS INCLUDED}

The first step in creating the WCYP database was the capture of the reported values and formats of the biomass yield data in a raw data excel spreadsheet that contained both metric and English units (appropriately identified with notes). Some form of aboveground yield information (as cumulative, incremental, or average biomass yields expressed as either green or dry weights) was necessary for inclusion of a given data set in the WCYP database. As long as one of the three growth parameters was reported, the others could be (and were) calculated. The originally reported numbers are shown in black text in the published WCYP database, whereas calculated values are shown in red text.

Publications reporting total aboveground dry weight data were preferred, but some excellent data sets were included that presented the yield data in terms of stem weights (generally inside bark weight). This type of data was deemed usable when the authors also provided some information on the allocation of weight among the stem, bark, branches, and foliage at several different ages. Publications that expressed growth patterns only in terms of the volume, basal diameter, breast height diameter, or height of the stem were not included in the published data set. However, information on heights, breast height diameter, basal diameters, basal areas, and other growth descriptors such as volume were included in the database when such information was provided in addition to aboveground weights. Standard errors of each 
measure were also included if provided numerically. Standard error information was generally not available when growth values were generated from graphic presentations of yield data.

It is appropriate to explain why volume measures were not considered to be a sufficient information source for this database. Our review of the woody crop production literature determined that tree volume is often estimated based on easily measured predictors (such as diameter at breast height and height and their transformations). However, a 2002 paper by Zhang et al. ${ }^{1}$ pointed out that such empirical relationships do not work equally well for volume prediction across regions or sites or between fertilized and non-fertilized treatments. Several earlier papers also identified regional differences in volume prediction equations. In particular, a 1986 conference paper ${ }^{2}$ presented data showing that application of empirically based biomass equations (for hardwood species) developed in one southeastern region and applied to another southeastern region usually resulted in yield estimation errors. While the errors were typically in the 0 to $10 \%$ range, they could be as great as $15 \%$ to $25 \%$. Alternative "mixed effect" models of volume based on taper were offered by Zhang et al. in $2002^{1}$ as being more accurate for estimating volumes across regions and sites. However, their model testing indicated that when converting taperbased volume equations to weights, a high degree of accuracy depends on using density values that vary as a function of tree height and age. Rarely are stem wood density values as a function of tree age made available in the literature. Thus it was concluded that even when both volume and weight equations were appropriately developed for stands in one location, they could not be applied, with a high degree of confidence, across regions. Issues such as these led to restricting the final WCYP database sources to papers that published weights (either green or dry) rather than volumes.

About 80 columns were required in the spreadsheet to capture all available and desired information on experimental treatments and conditions including species/clone names, multiple ways of expressing yield, size of total experimental field and treatment plots, survival percentages, and all treatment variables (e.g., spacing, fertilization types and levels, and irrigation). Columns not originally envisioned such as stem weights and "expansion factors," which applied to only a few of the information sources, were nevertheless added to the spreadsheet to allow appropriate calculation of total aboveground biomass yields as necessary.

The degree of completeness of information included in the WCYP database is highly variable, with many of the older sources of information being very incomplete but nevertheless included as points of reference. An attempt was made to fill all cells in the spreadsheets, either with reported or calculated values or with the number "-9999" to designate that the desired value had been searched for but was not found. In the case where an added column, such as expansion factors, clearly only applied to one or two information sources the cells were left blank in most rows.

\subsection{STANDARDIZATION OF THE DATA}

The second step in the WCYP database development involved the conversion of the raw data to similar units. Conversion of English units to metric units was needed for many database parameters. For key yield variables, both metric and English values were contained in the preliminary database but only metric values were retained for the publically available database. The conversion factors most often used are listed in Appendix A of this paper and included as a separate worksheet in the online WCYP database.

Application levels (pounds or kilograms) of a wide range of fertilizer types were converted to the amounts of the active ingredients nitrogen $(\mathrm{N})$, phosphorus $(\mathrm{P})$, and potassium $(\mathrm{K})$ added over the complete rotation to facilitate comparison of culture intensity levels. Appendix B focuses on how to translate the various fertilizer formulations used into mass weights of the elements $\mathrm{N}, \mathrm{P}$, and $\mathrm{K}$. 
All yield values in the WCYP database are expressed on a dry weight basis in metric units. It is common in the United States for forestry scientists to report biomass yields simply as "tons per acre," assuming the target audience of US field research foresters and forest industry managers will know that "green tons" are implied and that usually only the stem weight is included. However, academic studies of crop yields for biomass energy nearly always report biomass yields on a dry weight basis and include all aboveground components. These two different reporting conventions created the potential for misinterpretation of yield data. Direct contact was made with investigators where there was any uncertainty about whether yields were reported as green or dry tons and whether total or partial aboveground weights were being reported.

One difficulty in yield comparisons is not adequately resolved in the WCYP database. That difficulty is that published pine and eucalyptus data generally include foliage in the estimation of total aboveground biomass yield, whereas nearly all hardwood data (other than the eucalyptus) are collected during the dormant season when leaves are not on the trees, so foliage is not included. Allometry data (percent weights of stems, branches, leaves, and sometimes bark and roots) were available in some publications for specific species and locations but not for all locations and species. Thus the decision was made to accept the total aboveground dry weight numbers as published, which meant including pine and eucalyptus foliage but not including the foliage for all other hardwood species. This difference is potentially valid in situations where pines and eucalyptus are taken to boilers or biorefineries with most leaves intact. The concern then is the possible underestimation of yield in the few cases where other hardwoods might also arrive at boilers or biorefineries with intact leaves.

Another small standardization issue concerns yield comparisons between trees "coppiced" after the establishment year to create a multi-stemmed plant versus trees harvested as single stems. In coppice plantings, the documentation of productivity over time almost always starts with the first year of coppice growth (second year after planting) in the source literature, and thus the same convention is followed in the WCYP database. In single stem plantations, the documentation of productivity begins with the first planting year. If yield comparisons are made as a function of growth years, the coppiced stand almost always appears to have a growth advantage. If yield comparisons between coppiced and single-stem tree plantings are made on the basis of MAI $\max$, the number of years is irrelevant. The WCYP database contains columns for both stem age and root age, so database users could choose to recalculate the time to achieving $\mathrm{MAI}_{\max }$ in coppice stands based on root age rather than stem age if desired.

Both tree spacing (between and within row distances) and tree densities were included in the database. Most tree density numbers in the database are calculated based on the published tree spacing values. The calculation of density values was done with the intention of making it easy to find stands of equivalent density. However because the calculations were sometimes made starting from English units and sometimes made starting from reported metric units (which may or may not have been the actual planting units), it was found to be impossible to completely standardize across all experiments. This was especially true when the decision was made to use (from a few papers) the reported initial density values (that did not accurately reflect initial spacing descriptions) because of their prominent use in tables and graphics in the paper. The issues with standardizing tree density across experiments are explained in more detail in Appendix C. Nevertheless it is possible to sort the data based on tree density and thus identify experiments with roughly similar plant spacing.

Conversions not made included (1) conversion from bole volume to total aboveground biomass weights and (2) conversion of height and diameter data into biomass yield estimates. For either conversion, the potential for substantial error can be large unless appropriate equations can be found that have been developed for the same species, at a similar age, and within the same region. ${ }^{1,2}$ 
When only stem or bole weight yields were reported, it was necessary to apply an expansion factor to estimate total aboveground biomass yield. This was only necessary for two of the experimental data sets collected on pines ${ }^{3,4}$ and from the eucalyptus growth models generated by Langholtz et al. ${ }^{5}$ In the case of the pine data, appropriate expansion factors could be calculated using the species- and location-specific allometry information on bole, bark, branch, and leaf weights available as a function of age. ${ }^{4,6}$ Notes with more detail are provided as part of the published database. In the case of the eucalyptus data, the conversion factor of 1.7 suggested by Langholtz et al. ${ }^{5}$ was confirmed by comparing the data with eucalyptus allometry data provided in another paper summarizing several eucalyptus studies. ${ }^{7}$

It is worth mentioning that the scientific literature dealing with carbon cycles and carbon sequestration has dealt extensively with "biomass expansion factors" (BEFs) and equations for converting estimated stem weights or volumes to total aboveground biomass, though mostly for mature trees in forest stands. ${ }^{8}$ The Allometric Biomass and Carbon Factors database ${ }^{9}$ and the Biomass Compartments Database ${ }^{10}$ were created with information relevant to the Eurasian region. Meta-analysis of information in those databases ${ }^{11}$ provides insights on the effects of age, growing stock, and site index on BEFs. The database authors state that the ABC factors should be used with caution and only after understanding the source of the data and how the factors were defined by the original authors. ${ }^{8}$ Published allometry data on loblolly pines in the United States ${ }^{4,6}$ confirmed that the relationships between stem, branch, and leaf biomass percentages change considerably with age (particularly at younger ages) and vary with site-specific environmental conditions. Consequently, use of generic expansion factors, particularly those based on mature trees in mixed forests was deemed inappropriate for the WCYP database assembly exercise.

All database values resulting from conversions made in the process of data standardization are shown in red text and the originally reported units are shown in black text in the link to the published WCYP database found at the web address https://www.bioenergykdf.net/WCYP .

\subsection{IDENTIFICATION OF VALUES REPRESENTING MAI max $_{\operatorname{man}}$}

The third step in the data set development process was to study the woody crop growth patterns to determine the point (normally the year) when the mean value of annual growth or mean annual increment (MAI) is maximized (MAI $\mathrm{Max}_{\max }$ ) for the conditions being tested. Graphs were created of all multiyear growth information in the database to assist in visual evaluation of the data. The graphs, which can be found on the far right hand side of the WCYP growth pattern worksheet, were evaluated alongside the yield numbers and information on species, clones, planting density, and treatments. Data analysis results or statements in the text of the papers that were relevant to the status of the stand, such as information on canopy closure or basal area, were also helpful in drawing conclusions about the stand age associated with the $\mathrm{MAI}_{\max }$.

A relatively clear example of growth curves allowing verification of the $\mathrm{MAI}_{\max }$ year with confidence is found in Fig. 1 whereas a more confusing example is shown in Fig. 2. The MAI curve of Fig. 1 reaches a peak and levels out, the current annual increment (CAI) curve reaches a distinct peak then trends downward, and the data set contains measurements past the point of intersection of the MAI and CAI curves. Although Fig. 1 was one of the clearest examples of classic MAI and CAI growth curves, it was nevertheless necessary to consult the actual mean annual yield numbers associated with the curves to make the decision on the age of $\mathrm{MAI}_{\max }$. The downward shift in the CAI curve between years 4 and 5 , suggested that the $\mathrm{MAI}_{\max }$ could have been achieved in the 5th year of growth. However upon consulting the actual numbers, the 6th year showed a mean yield value just slightly higher than that of the 5th year. While the values differed by a very small fraction, it was decided that the year with the highest value for MAI (stand age 6) would be chosen to represent the yield potential of the stand. This aligns our decision with conventional wisdom, which suggests that the optimal harvest age occurs at the point where the MAI curve intersects the CAI curve. 


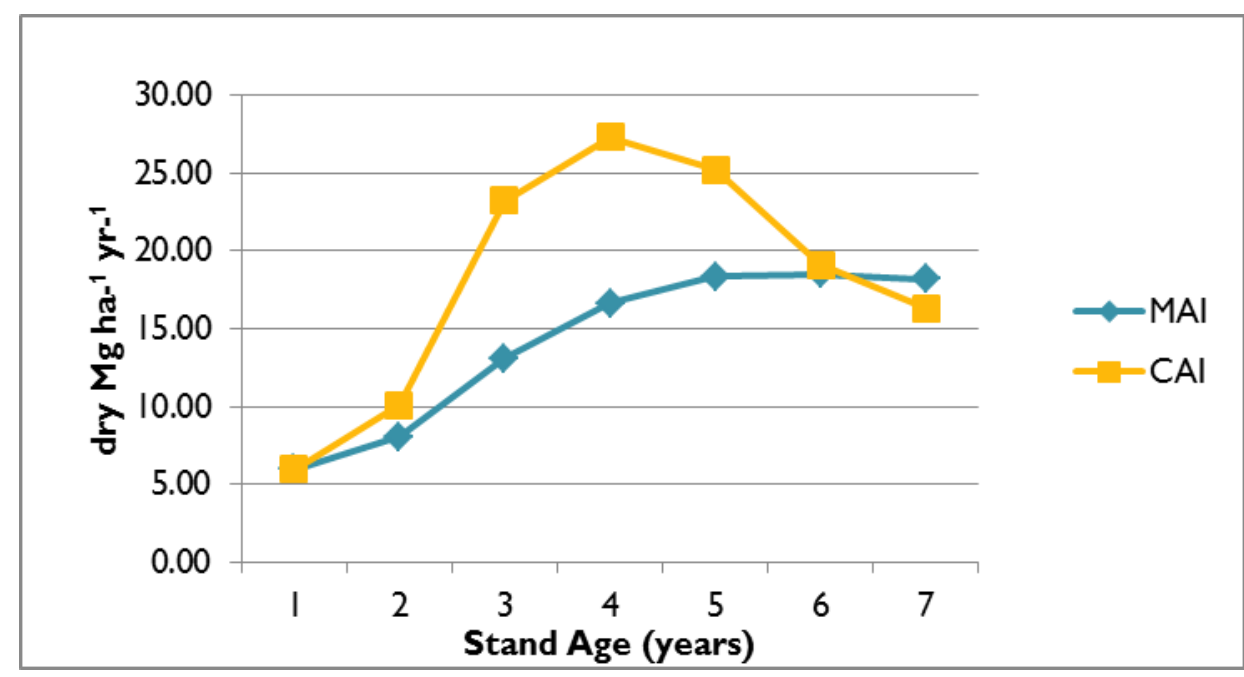

Fig. 1. Example of a relatively easy to interpret hybrid poplar growth pattern in a stand planted at about $\mathbf{1 0 , 0 0 0}$ trees $\mathbf{~ h a}^{-1}$. (MAI = mean annual increment; $\mathrm{CAI}=$ current annual increment.)

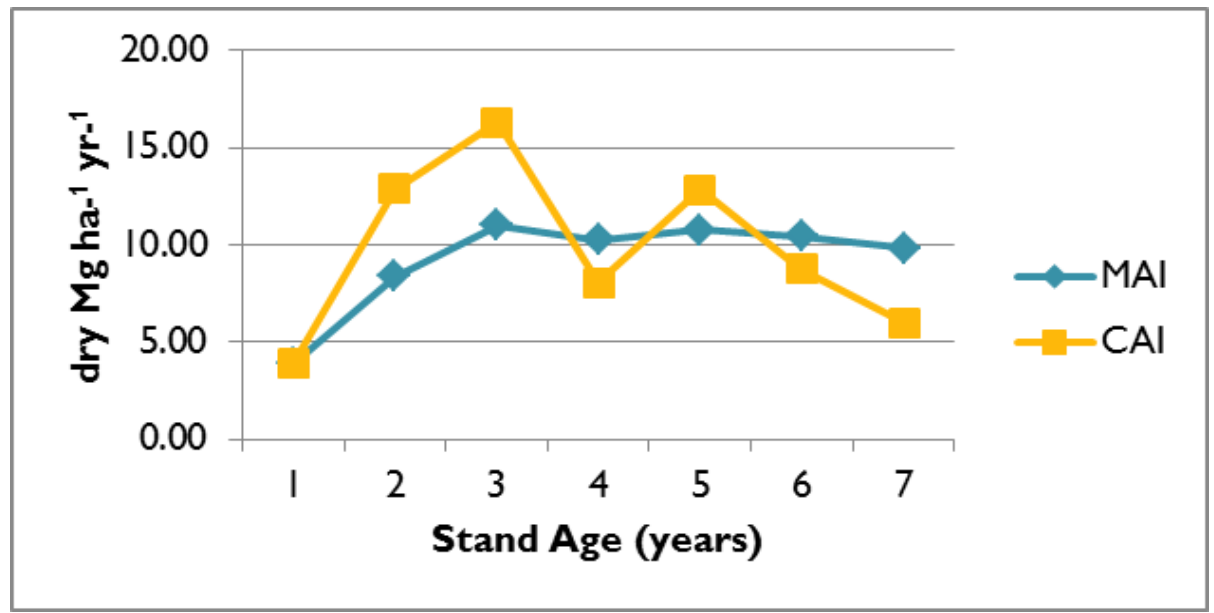

Fig. 2. Example of a more confusing hybrid poplar growth pattern in a stand planted at about 40,000 trees ha $\mathbf{~}^{-1}$. (MAI = mean annual increment; CAI = current annual increment.)

The Fig. 2 yield curve was produced in the same experiment as that of Fig. 1, but in a treatment using a different clone and a different planting density. While the site and climate conditions were the same for the Fig. 1 and 2 data sets, the planting density of the Fig. 2 data set is 4 times that of the data set represented in Fig. 1, and the clone differs. Both factors contributed to the $\mathrm{MAI}_{\max }$ being reached early in the experiment. The Fig. 2 data set differs from most others in the database in that the yield measurements were carried well beyond the point of $\mathrm{MAI}_{\max }$. Because the yield in year 3 is the highest yield measured during the duration of this treatment, the year 3 value was deemed to be the $\mathrm{MAI}_{\max }$ value for the data set represented in Fig. 2.

Many of the growth patterns observed in the data were very different from the smooth MAI and CAI growth curves shown in Fig. 1. Lack of continuous funding is a fact of life for woody crops researchers, frequently leading to incomplete or intermittent data collection. Decisions on $\mathrm{MAI}_{\max }$ status often had to 
be made with intermittent or incomplete data, or with growth patterns that were far from classic. The examples below (Figs. 3 and 4) required more thought and rationalization.

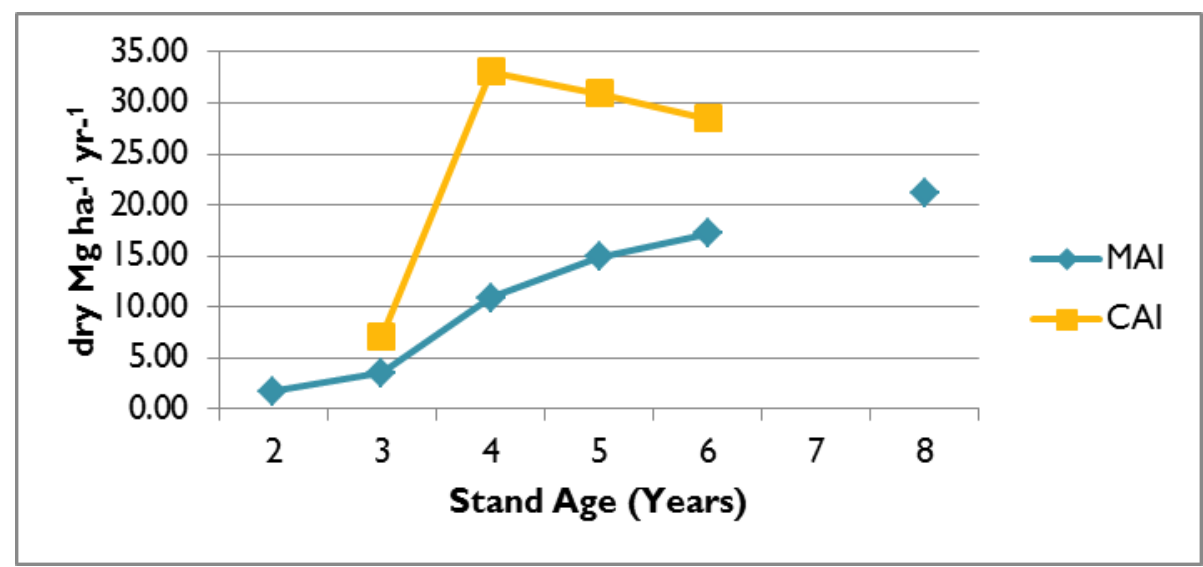

Fig. 3. Example of an incomplete growth data set for hybrid poplars planted at 1075 trees ha ${ }^{-1}$. (MAI = mean annual increment; CAI = current annual increment.)

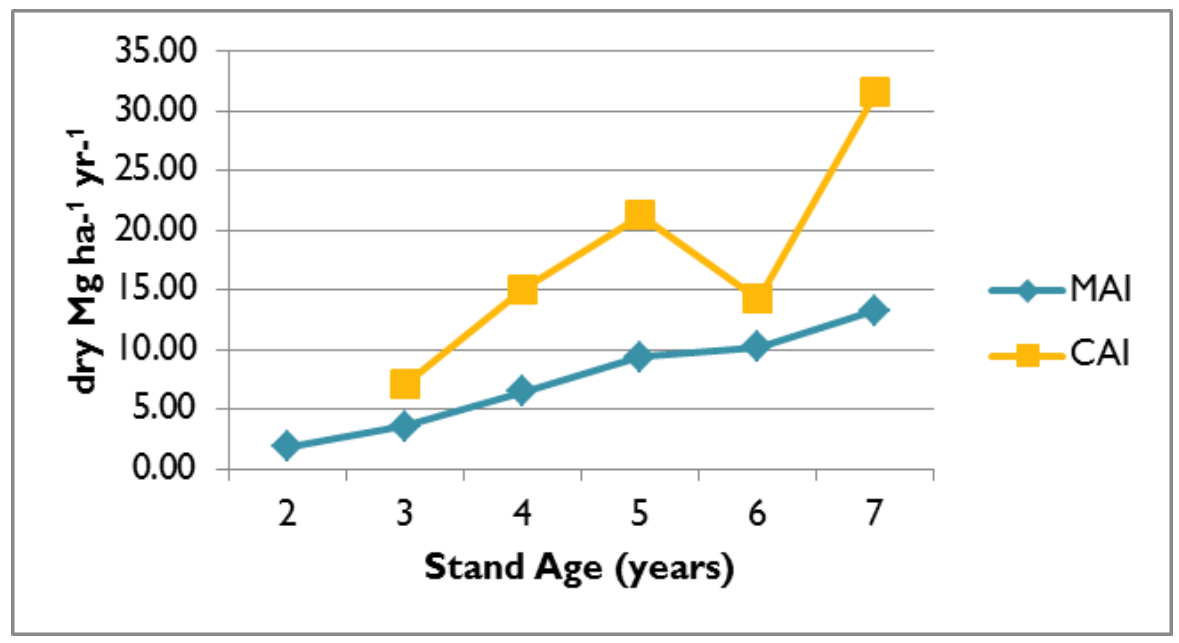

Fig. 4. Example of an atypical growth pattern of hybrid poplars planted at 1075 trees $\mathbf{h a}^{-1}$. (MAI = mean annual increment; $\mathrm{CAI}$ = current annual increment.)

An effort was made to consider the probable MAI status of the incomplete data set graphed in Fig. 3, primarily because of the higher than normal mean annual yield value collected in the 8th year of the study and the apparent clear downturn in the CAI curve as early as year 4. Based on the experience gained from studying the growth patterns of many data sets, it was believed that the CAI curve had a high probability of intersecting the MAI curve by age 8. But since validation of that belief was not possible, the yield is described as being "near" rather than "at" the $\mathrm{MAI}_{\max }$ in tables summarizing potential yield values.

The hybrid poplar planting density represented in Fig. 4 is the same as in Fig. 3; however, the location, the genotype, and planting years are different, all of which could explain the yield differences but not necessarily the growth pattern differences. In cases like this, where a large rise in the CAI occurs after an apparent downturn, the survival percentages would always be checked (if available) to determine whether a higher than normal mortality of some measurement trees might have allowed a growth spurt in the remaining trees. In this case, the survival of the measured trees was 100\% during the 7 years of 
measurement, so the explanation could not be found in the data set. Not documented was the possibility that poor climate conditions caused a slowdown in growth in the 6th year and much better conditions returned in year 7. Whatever the reasons for the distinct upturn in the CAI curve in year 7, the only conclusion that could be drawn was that measurement of the stand had not continued for enough time to identify the point of $\mathrm{MAI}_{\max }$. The data set was included in the WCYP database because the trial is believed to still be ongoing, and the potential for contributing additional information to the data set exists.

The growth patterns in annually harvested coppice plantings (Figs. 5 and 6) can be graphed in the same way as growth patterns in single stem plantings by summing all harvests to obtain cumulative growth over time, then dividing by stump age (or harvest years) to obtain the mean yield of the annually harvested crop over time. Some may disagree with the use of the MAI and CAI terms, but it seemed the most reasonable way to make the data comparable with multiple year rotation data.

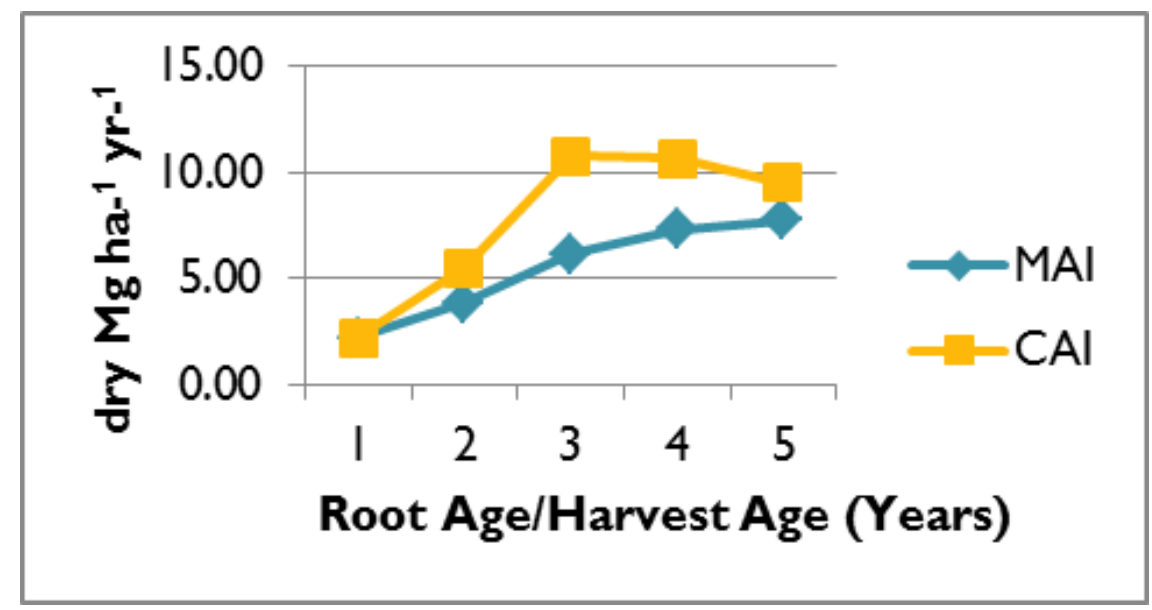

Fig. 5. Annually harvested willow coppice trials planted at more than 400,000 trees $\mathrm{ha}^{-1}$ and fertilized. (MAI = mean annual increment; CAI = current annual increment.)

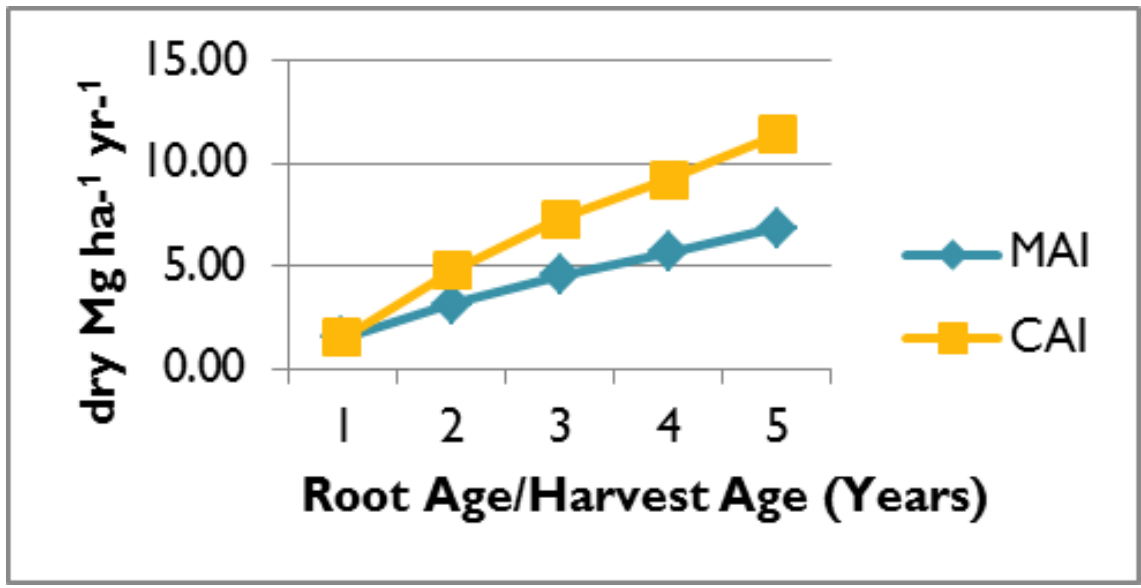

Fig. 6. Annually harvested willow coppice trials planted at more than 400,000 trees $\mathrm{ha}^{-1}$ with no fertilization. $(\mathrm{MAI}=$ mean annual increment; $\mathrm{CAI}=$ current annual increment.) 
It was concluded from Fig. 5 that the "CAI" of a fertilized treatment in a willow coppice stand had reached a maximum by age 3 , suggesting that by age 5 the stand was "near" its MAI $_{\max }$. On the other hand, in the unfertilized treatment of the same willow coppice stand (Fig. 6), the annually harvested yields showed no sign of slowing by age 5, and thus the $\mathrm{MAI}_{\max }$ could not be determined. Survival of the original stumps in the Fig. 5 data set was only 67\% by age 5 but was still 86\% by year 5 in the Fig. 6 data set. Neither data set was included in the set of data being identified as suitable for regional yield potential analysis because in both cases the final yields were much less than yields demonstrated by other treatments with the same species in the same area.

Figure 7 is another example of an incomplete data set, but it is included here to show that when pines are planted at very high density and intensively cultured they can show similar MAI curves to those of poplars and willows. It was deemed pointless to calculate the CAI values associated with the pine data set (Fig. 7) as the measurement in year 4 was missed. Although a little uncertainty exists due to the missing year 4 measurements, it is likely that because the MAIs for years 3 and 5 are similar, the stand was at least “near” MAI $\mathrm{max}_{\max }$ by year 5 .

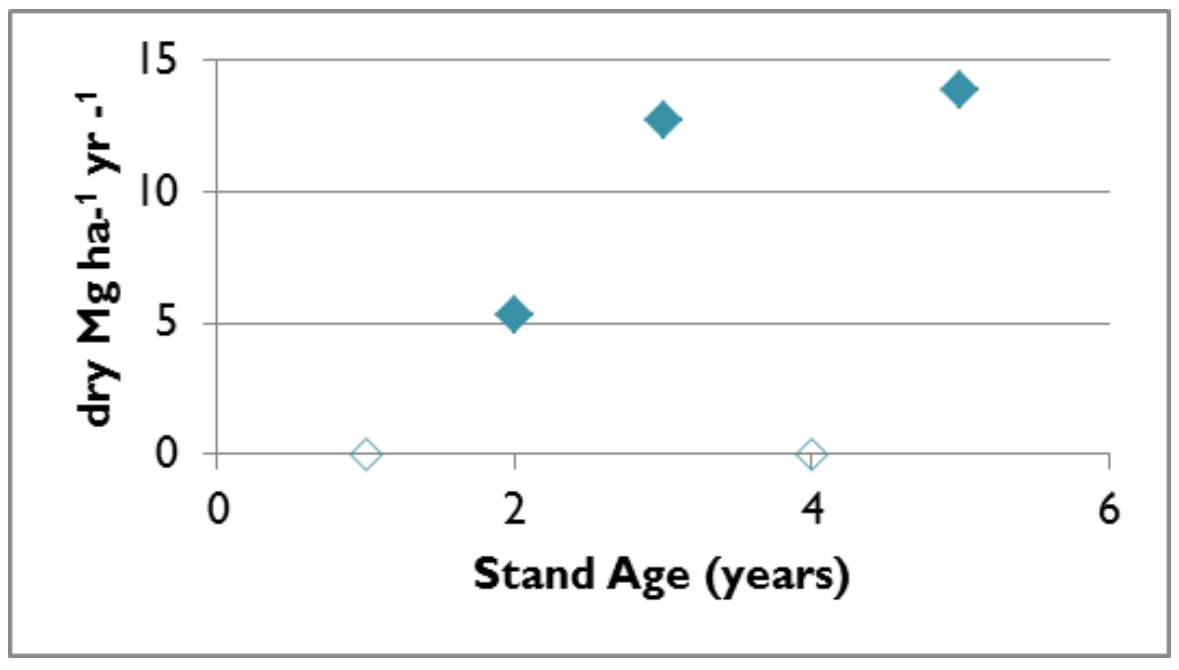

Fig. 7. Example of mean annual increment growth in an intensively cultured loblolly pine stand planted at 2,990 trees ha ${ }^{-1}$ with measurements taken only in years 2,3 , and 5.

Figure 8 shows an example of a growth curve that is nearly as straightforward as that found with the hybrid poplar stand represented in Fig. 1. The only problem is that the direction of the CAI curve totally changed in the last year of data collection. If the data collection had ended at year 14, it would have been assumed that the stand was near its point of $\mathrm{MAI}_{\max }$ as the CAI appeared to be clearly trending downward. However the increase of the CAI in year 15 makes it impossible to identify the point of actual $\mathrm{MAI}_{\text {max }}$. Given the relatively high density at which the pine stand was planted, it is suspected that density dependent mortality (77\% survival in year 15) may be releasing the remaining trees to obtain more growth. If so, the economically optimal harvest age may have been reached within the period of measurement. Even though the age of $\mathrm{MAI}_{\max }$ was not determined for this stand, the results were accepted as being representative of yield potential for the loblolly pine variety, under the management, and site conditions experienced. 


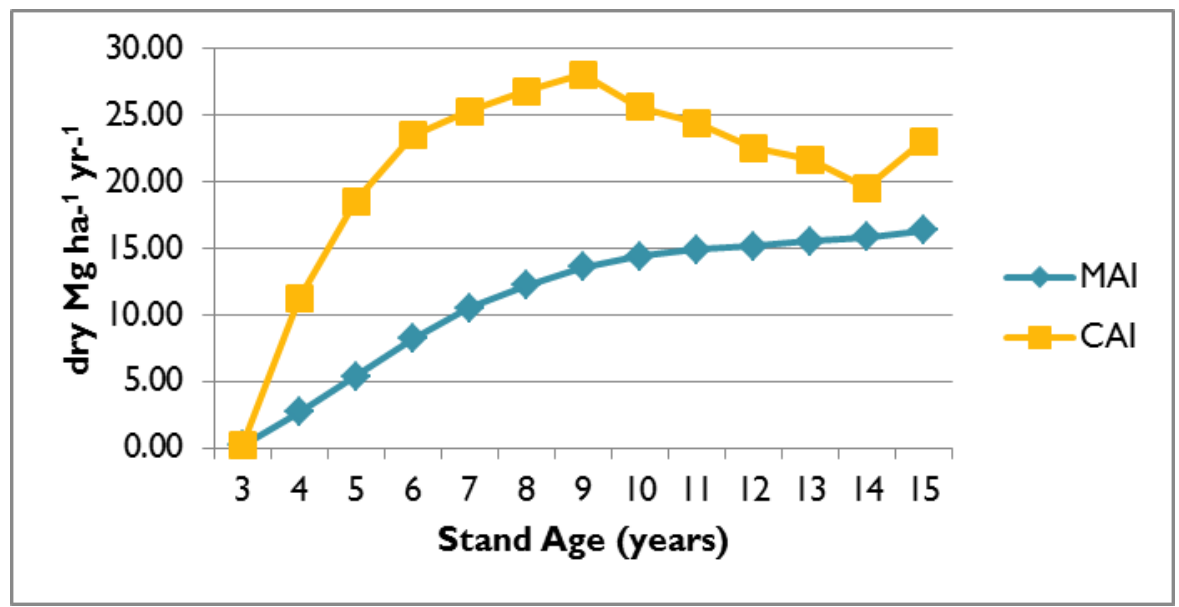

Fig. 8. Example of growth in an intensively cultured loblolly pine growth pattern planted at 1,660 trees $\mathrm{ha}^{-1}$. (MAI = mean annual increment; $\mathrm{CAI}=$ current annual increment.)

Figure 9 represents the more common growth pattern found in the loblolly pine studies. Even though planting densities were similar to at least some of the poplar plantings, the growth patterns were generally different. This could be a function either of species responses or of climate conditions. Severe drought conditions are more likely to be experienced in the southeastern United States than in the northern United States. The pine stands required a longer period of time to approach $\mathrm{MAI}_{\max }$, and the annual incremental growth was highly variable from year to year even with irrigated and fertilized treatments. Almost none of the loblolly pine trials were measured long enough to absolutely verify that $\mathrm{MAI}_{\max }$ had been reached even though they were observed for between 5 to 15 years.

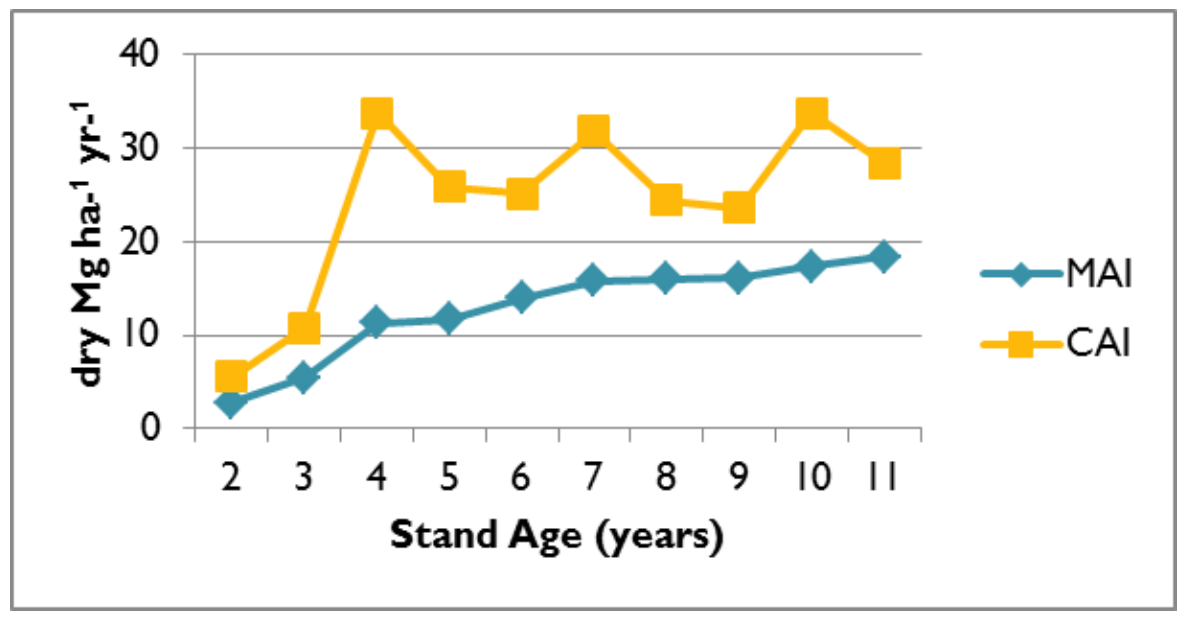

Fig. 9. Example of growth in an intensively cultured loblolly pine stand planted at 1,070 trees $\mathbf{h a}^{-1}$. $(\mathrm{MAI}=$ mean annual increment; $\mathrm{CAI}=$ current annual increment.)

When yield values are verified as clearly representing the stand age at MAI $\mathrm{max}_{\text {, }}$ a cell at the end of the appropriate row in the WCYP database (growth pattern worksheet) is highlighted in purple. Yield values deemed to be "near $\mathrm{MAI}_{\max }$ " are identified by a cell highlighted in pink at the end of the appropriate row in the WCYP database. These and other notations in the WCYP database are explained in the first few rows of the growth pattern worksheet. 


\subsection{IDENTIFICATION OF VALUES SUITABLE FOR YIELD POTENTIAL ANALYSIS}

When this project was initiated, it was decided that only data sets with yields verified to be at or near $\mathrm{MAI}_{\max }$ would be suitable for inclusion. However, once it was discovered that many of the data sets reporting high yields could not be verified to have reached the point of $\mathrm{MAI}_{\max }$, that constraint was relaxed. Thus results from trials reporting only the yields at the final year of measurement or at harvest were also be included in the WCYP database and accepted as a source of yield values suitable for yield potential analysis under some conditions. For example, final measurement results from experiments where high stocking densities were intended to promote rapid growth and where final yields approached high values ${ }^{12}$ were included. Also, if the experiment description stated that or data were provided indicating that the stand under investigation had reached canopy closure or culmination of periodic annual basal area or that the incremental yield growth was slowing before the final measurements, ${ }^{13}$ the data were included with confidence. In one case ${ }^{14}$, a paper only reported year 4 yields from a clone trial without much information to ascertain stand status, but another paper ${ }^{15}$ describing the same clone trial included published volume curves that clearly indicated that some or all of the clones had passed the point of $\mathrm{CAI}_{\max }$ by year 4 . In this case, the year 4 yield data were not only included in the WCYP, but also accepted as "near" $\mathrm{MAI}_{\max }$.

Thus in summary, yield data accepted as suitable for yield potential analysis and included in the WCYP SELECT worksheet had to meet at least one of the following criteria.

1. MAI was verified to be "at" its maximum value by MAI and CAI growth curves and the MAI $\mathrm{max}_{\max }$ yield exceeded 9 dry $\mathrm{Mg} \mathrm{ha}^{-1} \mathrm{yr}^{-1}\left(\sim 4\right.$ dry Tons $\left.\mathrm{ac}^{-1} \mathrm{yr}^{-1}\right)$

2. MAI was deemed "near" it maximum value, the text indicated canopy closure, and highest MAI yield exceeded 9 dry $\mathrm{Mg} \mathrm{ha}^{-1} \mathrm{yr}^{-1}$

3. MAI curve had reached a point where the rate of increase was level or falling and the highest MAI yield exceeded 11.6 dry $\mathrm{Mg} \mathrm{ha}^{-1} \mathrm{yr}^{-1}$ even though the growth data did not provide enough information to designate the $\mathrm{MAI}_{\max }$ point.

All experiments had at least two treatments at each location, and some had many treatments when similar plantings were established with multiple species or clones. Clonal trials might have as many as 50 to 100 clones being tested. If the number of clones being tested was 10 or fewer, then results of all clones were included in the WCYP growth pattern worksheet; however, in instances where yield results of many clones were reported, only the yield results of the top 5 to 10 clones were included in the WCYP growth pattern worksheet (a decision that is consistent with commercial recommendations). In a couple of the publications referenced, yield reporting was limited to the top three to five clones, the single best clone, and the average of two controls. If yield values for the individual controls could be found, they were included in the WCYP database as individual values rather than as control averages. If all treatments within a single experiment met one or more of the above three criteria, then only the best two or three treatments were chosen for inclusion in the WCYP SELECT worksheet. All data rows that contained the values considered to be useful for yield potential analysis were made to be bold in the complete WCYP growth pattern worksheet and copied as values into the WCYP SELECT worksheet. 


\subsection{DATABASE ASSEMBLY RESULTS}

The current set of data in the WCYP database is derived from 41 unique reference sources describing 79 experiments in the United States or southern Canada with a total of 473 different treatments. The database contains several worksheets. The worksheet that reports the complete yield curves contains roughly 1,660 rows of data and 81 columns of parameters reporting yields and associated treatment factors. Separate worksheets, linked by the source publication author and year, describe the sites and soils associated with each experiment; another separate worksheet assembles only the final yields deemed appropriate for yield potential analysis. Other worksheets contain conversion factors relevant to the database and notes pertaining to decisions made regarding organization of the data.

Of the 473 experimental treatments included in the 79 experiments described in the WCYP database, only 170 of the treatments provided sufficient growth pattern information for verifying that the measurements had included yield data deemed to be at or near the age of $\mathrm{MAI}_{\max }$. Thus only $36 \%$ of the treatments in the studies publishing woody crop growth curves were followed long enough to actually obtain the maximum average yield obtainable with that specific treatment. This is to be expected as once the maximum yields of the best treatment options are identified in an experiment, there is marginal value in continuing to measure the less than optimal treatment conditions of that experiment.

Fourteen of the publications included in development of the WCYP database did not report sufficient growth pattern information to verify the point of $\mathrm{MAI}_{\max }$ in any of the treatments evaluated. The results were nevertheless included for one or more of the following reasons: (1) the results provided useful or interesting site or treatment comparisons, (2) the authors believed the stands were at an appropriate harvest age for the chosen planting density, or (3) the experiments are continuing and additional data may become available.

Of the 170 treatments verified to be at or near $\mathrm{MAI}_{\max }$, only 101 of the treatments were considered useful for evaluating yield potential because some of the treatments were controls or low-culture intensity treatments that did not produce high yields. However some reported data, while not verifiable as $\mathrm{MAI}_{\max }$ values, were sufficiently high to be considered useful for yield analysis. Thus the final conclusion was that about 123 yield values (rows in the database) were of value for use in woody crop yield potential studies. These rows of data were copied and the values pasted into a separate worksheet within the total database (Excel spreadsheet) named "WCYP SELECT." This worksheet has also transformed into a searchable and sortable table that can be found at the web address https://www.bioenergykdf.net/WCYP . Descriptive information associated with this table will provide the link to the entire database.

Nevertheless, the WCYP database summarizes a very broad set of old and new standing biomass data from plantation-grown hardwoods and softwoods established under a wide range of conditions across the United States and Canada. Nearly all data sets included in the database were found in publically available information sources. The majority of those were peer-reviewed literature sources. In some cases, nonpeer-reviewed proceedings, papers, presentations, and student theses or dissertations also served as sources of yield data, particularly for some of the experimental details associated with the yield data. While electronically available, such sources cannot be easily found without intense and very specific internet searches. In some cases, use of multiple papers from the same research institution was required to obtain the desired level of detail on the experimental sites and methods. In a few cases, some experimental details were not found in public reports but were gleaned from the collection of unpublished biomass research subcontractor reports housed at ORNL. To the extent possible, those sources are being digitized and made available through ORNL websites.

During the initial sweep of data collection, many partial sets of yield data were typed into Excel tables that did not end up being included in the final WCYP database, largely because of the obvious 
incompleteness of the growth curves and because of the lack of supporting experimental details. It may appear that some obvious reports of yield results have been overlooked, but close inspection of multiple publications from the same institutions revealed that the same data were often published several times with a slightly different emphasis in each paper. In those cases, the one or two papers providing the best overall level of experimental detail were chosen to represent those data sets.

The current version of the WCYP database (circa 2012) does not include all information that could potentially be assembled for evaluating woody crop yield potential, particularly for the Southeast. Some new plantings are just beginning to generate data, some old and relatively new woody crop stands exist that have been measured for standing biomass, but the data have not yet been published, and some data that were provided for this database compilation exercise did not have enough supporting information to allow full interpretation of the data. It is hoped that this database will be used by others as a base set to which new data will be added over time. 


\section{YIELD SUMMARY TABLES}

\subsection{TABLE DESCRIPTIONS}

While the entire set of information associated with the high yielding trials cannot be included in this publication, a very good representation of the type of data assembled can be derived from the following tables which compare yields across the range of cultural treatments tested.

This publication includes tables with selected mean annual yield values from the database as a means of providing a condensed summary of a large portion of the database. The tables purposely show high, medium, and low mean annual yields of hardwoods within four regions of the United States (the Northeast, Southeast, North Central/Midwest, and Pacific Northwest) and pine yields in the Southeast using culture intensity as the grouping factor. The southeastern pine yields were included because the amount of data on southeastern hardwoods is limited and pines are an important biomass resource in the Southeast.

The data summarized in Tables 1 through 5 have been presented in a way that allows visual evaluation of several factors affecting woody crop yield potential. The tables group the data by regions, species, and culture intensity (where high intensity may be high stocking density, high fertilizer levels, weed control, pest control, irrigation inputs, and advanced generation genetic materials or combinations thereof). Because the $\mathrm{MAI}_{\max }$ values of a stand are the key values that should be used in making comparisons across species, sites, and regions, the $\mathrm{MAI}_{\max }$ values are used (when available) rather than the last measurements taken. All treatments measured or harvested before reaching $\mathrm{MAI}_{\max }$ are footnoted with an assessment of whether the final measurement or harvest of the treatment was approaching $\mathrm{MAI}_{\max }$. The footnotes, e, f, and g in the "Stem Age" column (representing age at which the stand was at or near $\mathrm{MAI}_{\max }$ are defined the same in Tables 1-4 regardless of the order in which they appear. Only one Loblolly pine dataset provided a growth curve allowing verification of the $\mathrm{MAI}_{\max }$ and that dataset is indicated by an asterisk $\left(^{*}\right)$ next to the stem age.

The loblolly pine trials in the Southeast offered data from well documented experiments established purposely to compare culture intensity levels. In other regions the comparisons were much less rigorous, generally involving similar species or clones established at different times, in different locations, and at different culture intensities. Consideration of site factors was very limited, but a notation was made when the text identified the sites as fertile, especially when fertilization was not involved.

As a means of demonstrating that silvicultural inputs as well as site factors need to be taken into account when evaluating the information in this database, some of the data sets were assembled in tables and grouped by silvicultural intensity levels. The tables include only a representative sample of the information in the WCYP database (Excel spreadsheet). The link to the entire database can found at https://www.bioenergykdf.net/WCYP. 
Table 1. Maximum mean annual yields from published growth curves of willow (Salix dasyclados) and hybrid poplar (Populus) in high density small plot silviculture and clone trials in the Northeast grouped by culture intensity level

\begin{tabular}{|c|c|c|c|c|c|c|c|c|}
\hline $\begin{array}{c}\text { Culture Intensity }^{\text {a }} \\
\text { and Location(s) }\end{array}$ & Genotypes $^{\mathrm{b}}$ & $\begin{array}{c}\text { Yield }^{\mathrm{c}} \\
\text { (oven dry Mg } \\
\text { ha }^{-1} \mathrm{yr}^{-1} \text { ) }\end{array}$ & $\begin{array}{c}\text { Stem } \\
\text { Age }^{\mathrm{d}} \\
\text { (rotation) }\end{array}$ & $\begin{array}{c}\text { Total Rotation } \\
\text { N, P, K } \\
\left(\mathrm{kg}^{-1} \mathbf{h a}^{-1}\right)\end{array}$ & $\begin{array}{c}\text { Plant } \\
\text { Density } \\
\left(\text { trees ha }^{-1}\right)\end{array}$ & $\begin{array}{c}\text { Survi } \\
\text { val } \\
(\%)\end{array}$ & $\begin{array}{l}\text { Plant } \\
\text { Year }\end{array}$ & $\begin{array}{c}\text { Reference } \\
\text { Source }\end{array}$ \\
\hline \multicolumn{9}{|c|}{ Very high intensity culture (weed control, irrigation, very high fertilization) } \\
\hline Tully, NY & & 15.0 & $1(1)$ & $224,112,112$ & 15,152 & 92 & & \\
\hline $\mathrm{T}, \mathrm{W}, \mathrm{I}, \mathrm{HF}$ & SV1 & 17.4 & $2(1)^{\mathrm{e}}$ & $448,224,224$ & 37,037 & 85 & 1990 & 16 \\
\hline $\mathrm{T}, \mathrm{W}, \mathrm{I}, \mathrm{HF}$ & SV1 & 23.8 & $3(1)^{\mathrm{e}}$ & $672,224,224$ & 37,037 & 66 & 1990 & 16,17 \\
\hline Tully, NY & & 27.5 & $3(1)^{\mathrm{e}}$ & 672, 224, 224 & 37,037 & NA & & \\
\hline $\mathrm{T}, \mathrm{W}, \mathrm{I}, \mathrm{HF}$ & NM5 & 8.8 & $1(5)^{f}$ & 336, 112, 224 & 111,111 & 26 & 1987 & 18 \\
\hline Tully, NY & SV1 & 11.6 & $1(5)$ & $336,112,224$ & 111,111 & 46 & & \\
\hline Huntingdon Co, PA & NE388 & 11.4 & $3(2)$ & non-limiting & 20,833 & 46 & & \\
\hline \multicolumn{9}{|c|}{ High Intensity culture (weed control, high fertilization) } \\
\hline $\mathrm{T}, \mathrm{W}, \mathrm{HF}$ & SV1 & 8.9 & $3(1)^{\mathrm{f}}$ & $672,224,224$ & 37,037 & NA & 1990 & 17 \\
\hline Tully, NY & & & & & & NA & & \\
\hline $\mathrm{T}, \mathrm{W}, \mathrm{F}$ & SV1 & 13.25 & $1(1)$ & Sludge-mulch ${ }^{\mathrm{h}}$ & 15,152 & NA & 1995 & 20 \\
\hline Tully, NY & & & & $1200,0,0$ & & NA & & \\
\hline $\mathrm{T}, \mathrm{W}, \mathrm{F}$ & SV1 & 11.6 & $2(1)$ & Slow release & 15,152 & NA & 1995 & 20 \\
\hline Tully, NY & & & & $100,0,0$ & & NA & & \\
\hline $\mathrm{T}, \mathrm{W}, \mathrm{F}$ & NE388 & 10.1 & $4(1)^{\mathrm{e}}$ & non-limiting & 20,833 & 83 & 1981 & 19 \\
\hline Huntingdon Co, PA & NE388 & 12.9 & $3(2)$ & non-limiting & 20,833 & 51 & & \\
\hline \multicolumn{9}{|c|}{ Medium intensity culture (weed control, irrigation) } \\
\hline $\mathrm{T}, \mathrm{W}, \mathrm{I}$ & NM5 & 9.8 & $1(5)$ & $0,0,0$ & 111,111 & 39 & 1987 & 18 \\
\hline Tully, NY & SV1 & 10.0 & $1(5)$ & $0,0,0$ & 111,111 & 39 & & \\
\hline Huntingdon Co, PA & NE388 & 10.0 & $3(2)$ & $0,0,0$ & 20,833 & 79 & & \\
\hline \multicolumn{9}{|c|}{ Low Intensity culture or experimental controls (weed control) } \\
\hline $\mathrm{T}, \mathrm{W}$ & SV1 & 8.4 & $3(1)^{f}$ & $0,0,0$ & 15,152 & NA & 1995 & 20 \\
\hline Tully, NY & & & & & & NA & & \\
\hline $\mathrm{T}, \mathrm{W}$ & NM6 & 18.1 & $4(1)^{\mathrm{g}}$ & $0,0,0$ & 18,146 & NA & 1999 & 21 \\
\hline SW of Montreal & SX64 & 16.9 & $4(1)^{\mathrm{g}}$ & $0,0,0$ & 18,146 & NA & & \\
\hline $\begin{array}{c}\text { T, W } \\
\text { Huntingdon Co, PA }\end{array}$ & NE388 & 9.4 & $4(1)^{\mathrm{e}}$ & $0,0,0$ & 109,649 & 67 & 1970 & 22 \\
\hline $\mathrm{T}, \mathrm{W}$ & NE388 & 8.4 & $4(1)^{\mathrm{g}}$ & $0,0,0$ & 20,833 & 89 & 1981 & 19 \\
\hline Huntingdon Co, PA & NE388 & 10.3 & $3(2)$ & $0,0,0$ & 20,833 & 82 & & \\
\hline
\end{tabular}

${ }^{\mathrm{a} C}$ Culture intensity notations are as follows: $\mathrm{T}=$ site preparation tillage, $\mathrm{W}=$ chemical weed control, $\mathrm{I}=\mathrm{irrigation}, \mathrm{F}=$ fertilization, $\mathrm{HF}=\mathrm{High}$ Fertilization, $\mathrm{P}=$ pest control.

bSVI (select clone of Salix dasyclados), NM5 (Populus nigra x P.maximowiczii), NE388 (Populus maximowiczii x P. trichorcarpa), SX64 (select clone of Salix miyabean).

${ }^{\text {c}}$ Yield is the mean annual increment (MAI) of the total aboveground dry weight (without foliage for hardwoods) at growth curve maximum or harvest.

${ }^{\mathrm{d}}$ The stem age column optimally reports the growth year in which the planted trees reached maximum mean annual increment (MAI max). When measurements did not extend over a sufficient number of years to verify $\mathrm{MAI}_{\max }$, footnotes describe the assumptions associated with the yield data. The stem age of stands that were "coppiced" at end of the establishment year is one year less than the stump age (unless annually harvested). Annually harvested coppice growth always shows stem age as 1 and the number in parenthesis is the harvest year (or rotation) in which the maximum average growth rate is obtained.

${ }^{\mathrm{e}}$ Age of $\mathrm{MAI}_{\max }$ was not verifiable but growth pattern suggested final harvest measurement likely to be close to $\mathrm{MAI}_{\max }$.

${ }^{\mathrm{f}}$ Age of $\mathrm{MAI}_{\max }$ was not verifiable but high density of planting suggests final measurement or harvest could be near appropriate harvest age

${ }^{\mathrm{g}}$ Age of $\mathrm{MAI}_{\max }$ was not verifiable but yield included to allow comparisons as function of location, species or culture intensity.

${ }^{\mathrm{h}}$ Nitrogen value of the sludge was $1200 \mathrm{~kg} \mathrm{ha}^{-1}$ all in organic form. 
Table 2. Maximum mean annual yields of poplars (Populus hybrids and Populus detoides), silver maple (Acer saccharinum), alder (Alnus glutinosa) and black locust (Robinia pseudoacacia) in small-plot silvicultural and clone trials in the North Central and Mid-west United States grouped by culture intensity level

\begin{tabular}{|c|c|c|c|c|c|c|c|c|}
\hline $\begin{array}{c}\text { Culture } \\
\text { Intensity }^{\mathrm{a}} \text { and } \\
\text { Location(s) }^{-}\end{array}$ & Genotypes $^{\text {b }}$ & $\begin{array}{c}\text { Yield }^{\mathrm{C}} \\
\text { (oven dry } \\
\text { Mg ha }^{-1} \mathrm{yr}^{-1} \text { ) }\end{array}$ & $\begin{array}{c}\text { Stem } \\
\text { Age }^{\mathrm{d}} \\
\text { (Rotation) }\end{array}$ & $\begin{array}{c}\text { Total Rotation } \\
\text { N, P, K } \\
\text { kg }^{-1} \mathbf{h a}^{-1}\end{array}$ & $\begin{array}{c}\text { Plant } \\
\text { Density } \\
\text { trees ha- }^{-1} \\
\end{array}$ & $\begin{array}{c}\text { Survival } \\
\%\end{array}$ & $\begin{array}{l}\text { Plant } \\
\text { Year }\end{array}$ & $\begin{array}{c}\text { Reference } \\
\text { Source }\end{array}$ \\
\hline \multicolumn{9}{|c|}{ Very high intensity culture (weed control, irrigation, non-limiting fertilization, high planting density) } \\
\hline T, W, I, HF, & NC5260 & 13.6 & $4(1)^{\mathrm{f}}$ & Non-limiting & 189,035 & 79 & 1970 & \multirow[t]{2}{*}{23} \\
\hline Rhinelander,WI & & 15.2 & $4(1)^{\mathrm{f}}$ & $\begin{array}{c}\mathrm{N}, \mathrm{P} \& \mathrm{~K}+ \\
\text { micronutrients }\end{array}$ & 111,111 & 88 & 1970 & \\
\hline \multicolumn{9}{|c|}{ High intensity culture (weed control, irrigation, high nitrogen, mostly high planting density) } \\
\hline T, W, I, F & NC5260 & 9.9 & $5(1)^{\mathrm{f}}$ & $560,0,0$ & 111,111 & NA & 1973 & \multirow[t]{2}{*}{24} \\
\hline Rhinelander,WI & & 8.7 & $9(1)^{f}$ & $996,0,0$ & 3,086 & NA & 1977 & \\
\hline $\mathrm{T}, \mathrm{W}, \mathrm{I}, \mathrm{F}$ & NE299 & 10.8 & $6(1)$ & $666,0,0$ & 27,778 & NA & 1977 & 24 \\
\hline \multicolumn{9}{|l|}{ Rhinelander,WI } \\
\hline $\mathrm{T}, \mathrm{W}, \mathrm{I}, \mathrm{F}$ & NE299 & 10.7 & $6(1)$ & $550,0,0$ & 27,778 & 36 & 1981 & \multirow[t]{2}{*}{25,26} \\
\hline Rhinelander,WI & & 7.2 & $5(2)$ & $550,0,0$ & 27,778 & 19 & 1978 & \\
\hline \multicolumn{9}{|c|}{ Medium intensity culture (weed control, irrigation or fertile floodplain, mostly high planting density) } \\
\hline $\mathrm{T}, \mathrm{W}, \mathrm{I}$ & NE41 & 12.8, & $6(1)$ & $0,0,0$ & 10,000 & 95 & 1981 & \multirow[t]{4}{*}{24} \\
\hline \multirow[t]{3}{*}{ Rhinelander,WI } & NE41 & 11.4 & $7(1)$ & $0,0,0$ & 5,000 & & & \\
\hline & NE386 & 11.4 & $6(1)$ & $0,0,0$ & 10,000 & 92 & 1981 & \\
\hline & NE386 & 9.2 & $7(1)$ & $0,0,0$ & 5,000 & & & \\
\hline $\mathrm{T}, \mathrm{W}$, I; fertile & P. deltoides & & & & & & & \multirow[t]{4}{*}{12} \\
\hline \multirow{3}{*}{$\begin{array}{c}\text { New Franklin, } \\
\text { MO }\end{array}$} & 26C6R51 & 10.6 & $5(1)^{f, g}$ & $0,0,0$ & 10,000 & 99 & 2000 & \\
\hline & 2059 & 11.6 & $5(1)^{f, g}$ & $0,0,0$ & 10,000 & 90 & 2000 & \\
\hline & 1112 & 10.6 & $5(1)^{f, g}$ & $0,0,0$ & 10,000 & 83 & 2000 & \\
\hline $\mathrm{T}, \mathrm{W}$; fertile & P. deltoides & 8.9 & $2(2)$ & $0,0,0$ & 6,727 & 98 & 1973 & \multirow[t]{4}{*}{27,28} \\
\hline \multirow[t]{3}{*}{ Manhatten, KA } & A. & & & & & & & \\
\hline & saccharinum & 10.6 & $2(2)$ & $0,0,0$ & 13,455 & 96 & 1973 & \\
\hline & A. glutinosa & 11.3 & $2(2)$ & $0,0,0$ & 26,909 & 95 & 1973 & \\
\hline \multirow{3}{*}{$\begin{array}{c}1, \mathrm{w} \text {; rertile } \\
\text { Manhatten, KA }\end{array}$} & P. deltoides & 6.3 & $1(2)$ & $0,0,0$ & 107.637 & NA & 1985 & \multirow[t]{3}{*}{28} \\
\hline & $R$. & & & & & & & \\
\hline & pseudoacacia & 9.1 & $1(2)$ & $0,0,0$ & 107.637 & NA & 1985 & \\
\hline
\end{tabular}

Medium intensity culture (very small plot clone trials on experimental farms with high soil quality)

\begin{tabular}{|c|c|c|c|c|c|c|c|c|}
\hline \multirow{3}{*}{$\begin{array}{c}\text { T, W } \\
\text { Arlington WI }\end{array}$} & & & & & & & & \multirow{3}{*}{29,30} \\
\hline & Best 5 of 59 & & & & & & & \\
\hline & poplar clones $^{\mathrm{b}}$ & 18.2 & $8(1)^{\mathrm{e}}$ & $0,0,0$ & 1075 & 100 & 1995 & \\
\hline Ames, IA & & 16.7 & $9(1)^{\mathrm{e}}$ & $0,0,0$ & 1075 & 100 & 1995 & \multirow{4}{*}{29,30} \\
\hline $\mathrm{T}, \mathrm{W}$ & Best 1 of 59 & & & & & & & \\
\hline Arlington, WI & poplar clones ${ }^{\mathrm{b}}$ & 21.9 & $8(1)^{\mathrm{e}}$ & $0,0,0$ & 1075 & 100 & 1995 & \\
\hline Ames, IA & & 24.5 & $9(1)^{e}$ & $0,0,0$ & 1075 & 100 & 1995 & \\
\hline \multicolumn{9}{|c|}{ Low Intensity or experimental controls } \\
\hline $\begin{array}{c}\mathrm{T}, \mathrm{W} \\
6 \text { locations } \\
\text { across } 4 \mathrm{NC} \\
\text { states }\end{array}$ & $\begin{array}{c}\text { Average of } \\
\text { DN17, DN34, } \\
\text { \& DN182 }\end{array}$ & $\begin{array}{c}4.0-8.7 \\
\text { range }\end{array}$ & $7-10(1)$ & $0,0,0$ & 1682 & 88 & 1987 & 26 \\
\hline $\begin{array}{c}\mathrm{T}, \mathrm{W} \\
6 \text { locations } \\
\text { across } 4 \mathrm{NC} \\
\text { states }\end{array}$ & $\begin{array}{c}\text { Average of } \\
\text { DN17, DN34, } \\
\text { \& DN182 }\end{array}$ & $\begin{array}{c}4.8-9.5 \\
\text { range }\end{array}$ & $6-9(1)$ & $0,0,0$ & 1682 & 88 & 1988 & 26 \\
\hline $\mathrm{T}, \mathrm{P}$ & P. deltoides & & & & & & & \multirow[t]{3}{*}{31} \\
\hline \multirow[t]{2}{*}{ Ames, Iowa, US } & $91 \times 04-03$ & 11.5 & $8(1)^{g}$ & $0,0,0$ & 1667 & 90 & 1998 & \\
\hline & D105 & 9.8 & $8(1)^{\mathrm{g}}$ & $0,0,0$ & 1667 & 100 & 1998 & \\
\hline
\end{tabular}

${ }^{\mathrm{a}}$ Culture intensity notations are as follows: $\mathrm{T}$ = site preparation tillage, $\mathrm{W}=$ chemical weed control, $\mathrm{I}=$ irrigation, $\mathrm{F}=$ fertilization, $\mathrm{HF}=\mathrm{High}$ Fertilization, $\mathrm{P}=$ pest control.

${ }^{b}$ All are Populus hybrids unless otherwise noted. NC5260. NE299,NC5331, NM6, NE41, NE388, DN17, DN34, and DN182, are older selected Populus hybrid clones. 26CR51, 2059, and 1112 are pure Populus deltoides clones collected and distributed by the Missouri Department of Conservation. 91x04-03 is a pure Populus deltoides selected by Iowa State University breeders.

'Yield is the mean annual increment (MAI) of the total aboveground dry weight (without foliage for hardwoods) at growth curve maximum.

${ }^{\mathrm{d}}$ The stem age column optimally reports the growth year in which the planted trees reached maximum mean annual increment (MAI max). When measurements did not extend over a sufficient number of years to verify $\mathrm{MAI}_{\max }$, footnotes describe the assumptions associated with the yield data. The stem age of stands that were "coppiced" at the end of the establishment year is one year less than the stump age (unless annually harvested). Annually harvested coppice growth always shows stem age as 1 and the number in parenthesis is the harvest year (rotation) in which the maximum average growth rate is obtained.

${ }^{\mathrm{e}}$ Age of $\mathrm{MAI}_{\max }$ was not verifiable but growth pattern suggested final harvest measurement likely to be close to MAI $\mathrm{I}_{\max }$.

${ }^{\mathrm{f}} \mathrm{Age}$ of $\mathrm{MAI}_{\max }$ was not verifiable but high density of planting suggests final measurement could be near appropriate harvest age.

${ }^{\mathrm{g}} \mathrm{Age}$ of $\mathrm{MAI}_{\max }$ was not verifiable but yield included to allow comparisons as function of location, species or culture intensity. 
Table 3. Maximum mean annual yields (or harvest yields) from published growth curves of cottonwood (Populus trichocarpa) and poplar (Populus) hybrids in small plot silvicultural and clone trials in the Pacific Northwest grouped by culture intensity level

\begin{tabular}{|c|c|c|c|c|c|c|c|c|}
\hline $\begin{array}{l}\text { Culture } \\
\text { Intensity }^{a} \text { and } \\
\text { Location }\end{array}$ & Genotypes $^{\mathrm{b}}$ & $\begin{array}{l}\text { Yield }^{\mathrm{c}} \\
\text { (oven dry } \mathrm{Mg} \\
\left.\mathrm{ha}^{-1} \mathrm{yr}^{-1}\right)\end{array}$ & $\begin{array}{l}\text { Stem Age }^{d} \\
\text { (Rotation) }\end{array}$ & $\begin{array}{l}\text { Total } \\
\text { Rotation } \\
\text { N, P, K } \\
\left(\mathbf{k g}^{-1} \mathbf{h a}^{-1}\right)\end{array}$ & $\begin{array}{l}\text { Plant } \\
\text { Density } \\
\text { (trees ha }^{-1} \text { ) }\end{array}$ & $\begin{array}{l}\text { Survival } \\
(\%)\end{array}$ & $\begin{array}{l}\text { Plant } \\
\text { Year }\end{array}$ & $\begin{array}{l}\text { Reference } \\
\text { Source }\end{array}$ \\
\hline \multicolumn{9}{|c|}{ Very High Intensity (very high fertilizer on fertile site, high fertilizer and very high density on less fertile site) } \\
\hline T, W, F; fertile & $15-029$ & 30.5 & $4(1)^{\mathrm{e}}$ & $500,0,0$ & 2,222 & $100^{7}$ & 1987 & 13 \\
\hline Puyallup, WA & $44-133$ & 31.2 & $4(1)^{\mathrm{e}}$ & $500,0,0$ & 2,222 & $100^{7}$ & & \\
\hline T, W ,I, F & $11-11$ & 7.1 & $1(1-3)$ & $200,43,74$ & 308,642 & 98 & 1986 & 32 \\
\hline Olympia, WA & D-01 & 7.4 & $1(1-5)$ & $200,43,74$ & 308,642 & 96 & & \\
\hline \multicolumn{9}{|c|}{ High Intensity (fertile site with select clones, high fertilizer and/or high density on less fertile sites) } \\
\hline $\mathrm{T}, \mathrm{W}$, I; fertile & $11-05$ & 23.1 & $4(1)^{\mathrm{f}}$ & $0,0,0$ & 10,000 & 100 & 1985 & 14 \\
\hline \multirow{4}{*}{ Puyallup, WA } & $11-11$ & 29.4 & $4(1)^{f}$ & $0,0,0$ & 10,000 & 100 & & \\
\hline & $19-56$ & 23.2 & $4(1)^{f}$ & $0,0,0$ & 10,000 & 100 & & \\
\hline & $44-136$ & 24.2 & $4(1)^{\mathrm{f}}$ & $0,0,0$ & 10,000 & 100 & & \\
\hline & $55-258$ & 29.2 & $4(1)^{f}$ & $0,0,0$ & 10,000 & 100 & & \\
\hline $\mathrm{T}, \mathrm{W}, \mathrm{F}$; fertile & P. trichocarpa & & & & & & & \\
\hline \multirow[t]{2}{*}{ Puyallup, WA } & 50 clone avg. & 12.5 & $4(1)^{\mathrm{f}}$ & $225,0,0$ & 6,944 & 74 & 1979 & $33,34,35$ \\
\hline & 50 clone avg. & 11.3 & $4(2)^{e}$ & $133,0,0$ & 6,944 & 74 & & \\
\hline T,W,F ; fertile & $11-11$ & 27.5 & $4(1)^{f}$ & $225,0,0$ & 6,944 & 95 & 1979 & $33,34,35$ \\
\hline Puyallup, WA & $11-11$ & 43.5 & $4(2)^{e}$ & $133,0,0$ & 6,944 & 95 & & \\
\hline T,W,F; fertile & $11-05$ & 27.8 & $4(1)^{f}$ & $225,0,0$ & 6,944 & 95 & 1979 & $33,34,35$ \\
\hline Puyallup, WA & $11-05$ & 33.5 & $4(2)^{e}$ & $133,0,0$ & 6,944 & 95 & & \\
\hline $\mathrm{T}, \mathrm{W}, \mathrm{I}, \mathrm{F}$ & $11-11$ & 17.7 & $5(1)$ & $200,43,83$ & 40,000 & 95 & 1986 & 36 \\
\hline \multirow[t]{2}{*}{ Olympia, WA } & $11-11$ & 18.5 & $6(1)$ & $200,43,83$ & 10,000 & 95 & & \\
\hline & $11-11$ & 17.1 & $7(1)^{\mathrm{g}}$ & $300,43,83$ & 2,500 & 95 & & \\
\hline $\mathrm{T}, \mathrm{W}, \mathrm{F}$ & P. trichocarpa & 10.4 & $4(3)^{g}$ & Multiple & 111,111 & 47 & 1967 & 37 \\
\hline \multirow{2}{*}{$\begin{array}{l}\text { Mt Vernon, } \\
\text { WA }\end{array}$} & P. trichocarpa & 10.8 & $2(2)^{g}$ & levels - no & 26,874 & 53 & & \\
\hline & P. trichocarpa & 9.2 & $4(3)^{g}$ & effect & 6,719 & 83 & & \\
\hline \multicolumn{9}{|c|}{ Low Intensity or Experimental Controls } \\
\hline \multirow{5}{*}{$\begin{array}{c}\text { T, W, } \\
\text { Sumner, WA }\end{array}$} & P. trichocarpa & 7.9 & $8(1)^{\mathrm{g}}$ & $0,0,0$ & 111,111 & 95 & 1971 & 37 \\
\hline & P. trichocarpa & 9.6 & $8(1)^{g}$ & $0,0,0$ & 26,874 & 95 & & \\
\hline & P. trichocarpa & 6.6 & $8(1)^{g}$ & $0,0,0$ & 6,719 & 95 & & \\
\hline & P. trichocarpa & 5.6 & $8(1)^{g}$ & $0,0,0$ & 4,479 & 95 & & \\
\hline & P. trichocarpa & 7.6 & $8(1)^{g}$ & $0,0,0$ & 2,986 & 95 & & \\
\hline $\mathrm{T}$, W; fertile & $15-029$ & 25.9 & $4(1)^{\mathrm{e}}$ & $0,0,0$ & 2,222 & 100 & 1987 & 13 \\
\hline Puyallup, WA & $44-136$ & 27.5 & $4(1)^{e}$ & $0,0,0$ & 2,222 & 100 & & \\
\hline
\end{tabular}

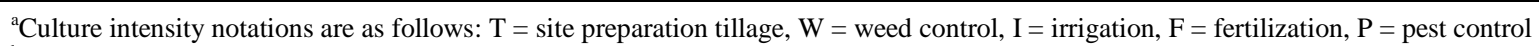
${ }^{\mathrm{b}}$ All are Populous hybrids unless otherwise noted. 15-029, 44-133, 11-05, 11-11, 19-56, 44-136, and 55-258 are selected clones of Populus deltoides x P. trichocarpa, many resulting from breeding by Reini Stettler at the University of Washington in the 1970 's. D-01 is a hybrid poplar clone of unknown origin deployed by Dula's nursery in Washington or Oregon.

'Yield is the mean annual increment (MAI) of the total aboveground dry weight (without foliage for hardwoods) at growth curve maximum or harvest.

${ }^{\mathrm{d}}$ The stem age column optimally reports the growth year in which the planted trees reached $\mathrm{MAI}_{\text {max }}$ based on published growth curves. When measurements did not extend over sufficient years to verify $\mathrm{MAI}_{\max }$, footnotes describe the assumptions associated with the yield data.

${ }^{\mathrm{e}}$ Age of $\mathrm{MAI}_{\max }$ was not verifiable but growth pattern suggested final harvest measurement likely to be close to $\mathrm{MAI}_{\max }$.

${ }^{\mathrm{f}}$ Age of $\mathrm{MAI}_{\max }$ was not verifiable but high density of planting suggests stand could be near appropriate harvest age.

${ }^{\mathrm{g}}$ Age of $\mathrm{MAI}_{\max }$ was not verifiable but yield included to allow comparisons as function of location, species or culture intensity. 
Table 4. Maximum mean annual yields (or final measurements) from published growth curves of hardwoods (sweetgum, Liquidambar styraciflua; sycamore, Platanus occidentalis; Eucalyptus, Eucalyptus grandis and Eucalyptus amplifolia; water-willow oak, Quercus sp.) in small plot silvicultural trials evaluated in the southern United States grouped by culture intensity level

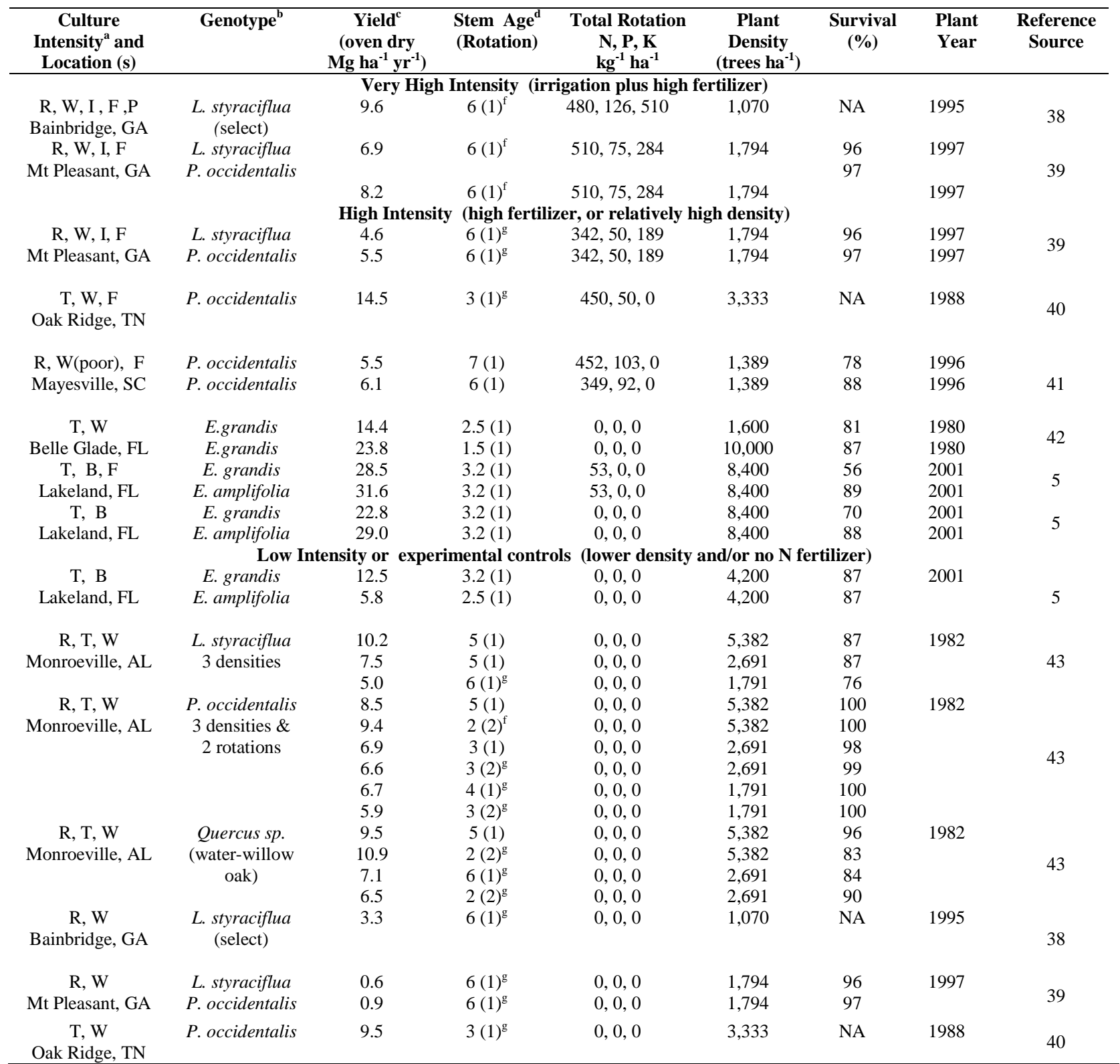

${ }^{\mathrm{a} C u l t u r e}$ intensity notations are as follows: $\mathrm{R}$ = ripped for site preparation, $\mathrm{T}=$ site preparation tillage, $\mathrm{W}=$ chemical weed control, $\mathrm{I}=$ irrigation, $\mathrm{F}=$ fertilization, $\mathrm{B}=$ bedding, $\mathrm{P}=$ pest control.

${ }^{\mathrm{b}}$ Tree genotypes used in these experiments were unselected, open pollinated seedlings unless otherwise noted.

${ }^{c}$ Yield is the mean annual increment (MAI) of the total aboveground dry weight (without foliage for hardwoods) at growth curve maximum or harvest.

${ }^{\mathrm{d}}$ The stem age column optimally reports the growth year in which the planted trees reached maximum mean annual increment (MAI max) based on published growth curves. When measurements did not extend over a sufficient number of years to verify $\mathrm{MAI}_{\max }$, footnotes describe the assumptions associated with the yield data.

${ }^{\mathrm{e}} \mathrm{Age}$ of $\mathrm{MAI}_{\max }$ was not verifiable but growth pattern suggested final measurement likely to be close to $\mathrm{MAI}_{\max }$ (none on this table).

${ }^{\mathrm{f}}$ Age of MAI $\mathrm{max}_{\text {max }}$ was not verifiable but high density of planting suggests final measurement or harvest was near appropriate harvest age

${ }^{\mathrm{g}}$ Age of $\mathrm{MAI}_{\max }$ was not verifiable but yield included to allow comparisons as a function of location, species or culture intensity. 
Table 5. Near maximum mean annual yields (or final measurements) from published growth curves of loblolly pine (Pinus taeda L.) evaluated in southeastern small plot silvicultural trials grouped by culture intensity level

\begin{tabular}{|c|c|c|c|c|c|c|c|c|}
\hline $\begin{array}{c}\text { Culture } \\
\text { Intensity and } \\
\text { Location (s) }^{\mathrm{a}}\end{array}$ & Genotype $^{b}$ & $\begin{array}{c}\text { Yield }^{\mathrm{c}} \\
\text { (oven dry Mg } \\
\text { ha }^{-1} \mathrm{yr}^{-1} \text { ) }\end{array}$ & $\begin{array}{l}\text { Stem } \\
\text { Age }^{\text {d }}\end{array}$ & $\begin{array}{c}\text { Total Rotation } \\
\text { N, P, K } \\
\left(\mathbf{k g}^{-1} \mathbf{h a}^{-1}\right)\end{array}$ & $\begin{array}{c}\text { Plant } \\
\text { Density } \\
\text { trees ha }^{-1}\end{array}$ & $\begin{array}{c}\text { Survival } \\
\%\end{array}$ & $\begin{array}{l}\text { Plant } \\
\text { Year }\end{array}$ & $\begin{array}{c}\text { Reference } \\
\text { Source }\end{array}$ \\
\hline \multicolumn{9}{|c|}{ Very High Intensity (high fertilizer plus most with additional treatments) } \\
\hline $\begin{array}{c}\text { W, I, F, P } \\
\text { Bainbridge GA }\end{array}$ & Family 7-56 & 18.4 & 11 & $980,241,953$ & 1070 & 76 & 1995 & 3 \\
\hline $\begin{array}{c}\text { W , I, F } \\
\text { Bainbridge GA }\end{array}$ & Family 7-56 & 19.2 & 11 & 980, 241, 953 & 1070 & 84 & 1995 & 3 \\
\hline $\begin{array}{c}\text { W, I, F, P } \\
\text { Bainbridge GA }\end{array}$ & 4 family avg & 15.2 & 6 & $537,126,510$ & 1070 & NA & 1995 & 38 \\
\hline $\begin{array}{l}\text { W, HF (Wet) } \\
\text { Waycross, GA }\end{array}$ & Family 7-56 & 17.0 & 15 & $1254,200,181$ & 1660 & 79 & 1987 & 4 \\
\hline $\begin{array}{l}\text { W, HF (Dry) } \\
\text { Waycross, GA }\end{array}$ & Family 7-56 & 16.4 & 15 & $1254,200,181$ & 1660 & 87 & 1987 & 4 \\
\hline $\begin{array}{c}\text { HF (Wet) } \\
\text { Waycross, GA }\end{array}$ & Family 7-56 & 16.4 & 15 & $1254,200,181$ & 1660 & 77 & 1987 & 4 \\
\hline $\begin{array}{c}\text { HF (Dry) } \\
\text { Waycross, GA }\end{array}$ & Family 7-56 & 15.2 & 15 & $1254,200,181$ & 1660 & 76 & 1987 & 4 \\
\hline $\begin{array}{c}\text { W, I, HF } \\
\text { Mt Pleasant, GA }\end{array}$ & Family 7-56 & 12.0 & 6 & $684,100,378$ & 1794 & 99 & 1997 & 39 \\
\hline \multicolumn{9}{|c|}{ High Intensity (weed control with fertilizer and/or irrigation) } \\
\hline $\begin{array}{c}\text { W, I } \\
\text { Bainbridge, GA }\end{array}$ & Family 7-56 & 16.1 & 11 & $0,0,0$ & 1070 & 85 & 1995 & 3 \\
\hline $\begin{array}{c}\text { W, I, F } \\
\text { Bainbridge, GA }\end{array}$ & 4 family avg & 11.5 & 6 & $537,126,510$ & 1070 & $\mathrm{NA}^{7}$ & 1995 & 38 \\
\hline $\begin{array}{c}\text { W, I, F } \\
\text { Mt Pleasant, GA }\end{array}$ & Family 7-56 & 13.2 & 6 & $510,75,284$ & 1794 & 99 & 1997 & 39 \\
\hline $\begin{array}{c}\text { W, I, F } \\
\text { Mt Pleasant, GA }\end{array}$ & Family 7-56 & 10.9 & 6 & $342,50,189$ & 1794 & 99 & 1997 & 39 \\
\hline $\begin{array}{c}\text { W, F } \\
\text { Sanderson, FL }\end{array}$ & $\begin{array}{c}7 \text { full-sib } \\
\text { family+mix }\end{array}$ & 13.2 & 5 & $369,128,121$ & 2990 & 92 & 2000 & 44 \\
\hline $\begin{array}{c}\text { W, F } \\
\text { Waverly, GA }\end{array}$ & $\begin{array}{l}7 \text { full-sib } \\
\text { family+mix }\end{array}$ & 13.9 & 5 & $369,128,121$ & 2990 & 92 & 2000 & 44 \\
\hline $\begin{array}{c}\text { W, F } \\
\text { Gainsville, FL }\end{array}$ & $\begin{array}{l}\text { Improved } \\
1^{\text {st }} \text { gen fam }\end{array}$ & 12.2 & $11^{*}$ & $360,143,317$ & 1495 & NA & 1983 & 45 \\
\hline \multicolumn{9}{|c|}{ Medium Intensity (weed control or fertilization) } \\
\hline $\begin{array}{c}\text { W } \\
\text { Bainbridge GA }\end{array}$ & Family 7-56 & 11.7 & 11 & $0,0,0$ & 1070 & 86 & 1995 & 3 \\
\hline $\begin{array}{c}\text { W (Wet) } \\
\text { Waycross, GA }\end{array}$ & Family 7-56 & 9.1 & 15 & $0,0,0$ & 1660 & 98 & 1987 & 4 \\
\hline $\begin{array}{c}\text { W (Dry) } \\
\text { Waycross, GA }\end{array}$ & Family 7-56 & 11.2 & 15 & $0,0,0$ & 1660 & 93 & 1987 & 4 \\
\hline $\begin{array}{c}\text { F (at planting), } \\
\text { Waverly, GA }\end{array}$ & $\begin{array}{c}7 \text { full-sib } \\
\text { family +mix }\end{array}$ & 11.5 & 15 & $50,56,0$ & 2990 & 93 & 2000 & 44 \\
\hline $\begin{array}{l}\text { F (at planting), } \\
\text { Sanderson, FL }\end{array}$ & $\begin{array}{l}7 \text { full-sib } \\
\text { family +mix }\end{array}$ & 8.1 & 5 & $50,56,0$ & 2990 & 93 & 2000 & 44 \\
\hline \multicolumn{9}{|c|}{ Low Intensity or Experimental Controls } \\
\hline $\begin{array}{c}\text { W } \\
\text { Bainbridge, GA }\end{array}$ & 4 family avg & 8.1 & 6 & $0,0,0$ & 1070 & NA & 1995 & 38 \\
\hline $\begin{array}{c}\text { T (Wet) } \\
\text { Waycross, GA }\end{array}$ & Family 7-56 & 7.5 & 15 & $0,0,0$ & 1660 & 98 & 1987 & 4 \\
\hline $\begin{array}{c}\text { T (Dry) } \\
\text { Waycross, GA }\end{array}$ & Family 7-56 & 8.4 & 15 & $0,0,0$ & 1660 & 86 & 1987 & 4 \\
\hline $\begin{array}{c}\mathrm{T} \\
\text { Mt Pleasant, GA }\end{array}$ & Family 7-56 & $7.3^{7}$ & 6 & $0,0,0$ & 1794 & 99 & 1997 & 39 \\
\hline $\begin{array}{c}\mathrm{T} \\
\text { Gainsville, FL }\end{array}$ & $\begin{array}{c}\text { Improved } \\
1^{\text {st }} \text { gen fam }\end{array}$ & 3.8 & 13 & $0,0,0$ & 1495 & NA & 1983 & 45 \\
\hline
\end{tabular}

${ }^{\mathrm{a} C u l t u r e}$ intensity notations are as follows: $\mathrm{T}$ = tillage used in site preparation, $\mathrm{W}=$ chemical weed control, $\mathrm{I}=$ irrigation, $\mathrm{F}=$ fertilization, $\mathrm{HF}=$ high fertilization, $\mathrm{P}=$ pest control.

${ }^{\mathrm{b}}$ Loblolly pine Family $7-26$ and the 4 family average are $2^{\text {nd }}$ generation selections, the 7 full-sib family + mix is $1^{\text {st }}$ generation

${ }^{c}$ Yield is the mean annual increment (MAI) of the total aboveground dry weight (including foliage for softwoods) at growth curve maximum or harvest. Expansion factors were used to convert published stem dry weights to total aboveground dry weight.

${ }^{\mathrm{d}}$ The stem age column optimally reports the growth year in which the planted trees reached $\mathrm{MAI}_{\max }$ based on published growth curves. However only 1 set of results (the starred value ) provided a growth curve which could be verified to reach $\mathrm{MAI}_{\max }$. However many of the experiments were measured to the point of being deemed near an appropriate harvest age for the initial planting density 


\subsection{BRIEF SUMMARY OF TREATMENT EFFECTS ON WOODY CROP YIELDS}

The culture intensity levels used in the experiments described in the literature vary greatly as a function of experimental type (clone comparisons versus silviculture testing, original site conditions, species, level of genetic improvement, and choice of fertilizer types) thus comparisons across trials is difficult. However, the yield summary tables do demonstrate some key points about the woody crop data that are currently available in the open literature.

1. High culture intensity nearly always produces higher yields than low culture intensity within a given site, but comparisons across sites can show great differences in yield with similar levels of culture intensity.

2. The importance of site quality factors (e.g. dry vs wet soils, prior nutrient status of the soil) is clearly demonstrated in some of the experimental trials summarized in these tables.

3. Achievement of high yield potential is a function of selecting high quality sites as well as the best performing genotypes for the site conditions selected.

4. The MAI $I_{\max }$ point cannot yet be identified in enough locations to have confidence that regional yield potentials can be appropriately characterized based on statistical analysis of existing woody crop data.

Because of the difficulty in making valid comparisons across sites and experimental conditions, no attempt was made to statistically analyze the data as a function of culture intensity or region. The data does show, however, that yields can sometimes be very high (> $20 \mathrm{Mg} \mathrm{ha}^{-1} \mathrm{yr}^{-1}$ ) under high-intensity cultural treatments or when selected clones are matched to good site conditions. While the data summarized by the WCYP database and this report are not sufficient to confidently predict potential woody crop yields as a function of region level across the United States, it does indicate that with careful selection of clones or varieties and appropriate management practices, yields of at least $15 \mathrm{Mg} \mathrm{ha}^{-1} \mathrm{yr}^{-1}$ can be obtained in most crop growing regions of the United States.

The Woody Crop Yield Potential Database was created with the goal of increasing awareness of what is available in the literature with respect to yield evaluations and to make that information more broadly available so that it could be used by others to conduct further analysis on woody crop yields in the United States and Canada. It is hoped that much more information will be collected and added to the database (excel spreadsheet). A link the entire database can be found on the DOE Bioenergy Knowledge Discovery Framework at the web address https://www.bioenergykdf.net/WCYP . 



\section{REFERENCES}

1. Y. Zhang, B. E. Borders, and R. L. Bailey, "Derivation, Fitting, and Implication of a compatible Stem Taper-Volume-Weight System for Intensively Managed, Fast Growing Loblolly Pine,” Forest Science, vol. 48, pp. 595-607, 2002.

2. A. Clark III, "Comparison of regional southern hardwood species weight and volume equations," presented at the 8th Annual Southern Forest Biomass Workshop, Knoxville, TN, 1986.

3. L. J. Samuelson, J. Butnor, C. Maier, T. A. Stokes, K. Johnsen, and M. Kane, "Growth and physiology of loblolly pine in response to long-term resource management: defining growth potential in the southern United States,” Canadian Journal of Forest Research, vol. 38, pp. 721-732, 2008.

4. B. E. Borders, R. E. Will, D. Markewitz, A. Clark, R. Hendrick, R. O. Teskey, et al., "Effect of complete competition control and annual fertilization on stem growth and canopy relations for a chronosequence of loblolly pine plantations in the lower coastal plain of Georgia," Forest Ecology and Management, vol. 192, pp. 21-37, 2004.

5. M. Langholtz, D. R. Carter, D. L. Rockwood, and J. R. R. Alavalapati, “The economic feasibility of reclaiming phosphate mined lands with short-rotation woody crops in Florida,” Journal of Forest Economics, vol. 12, pp. 237-249, 2007.

6. L. J. Samuelson, K. Johnsen, and T. Stokes, "Production, allocation, and stemwood growth efficiency of Pinus taeda L. stands in response to 6 years of intensive management,” Forest Ecology and Management, vol. 192, pp. 59-70, 2004.

7. P. Soares and M. Tome, "Analysis of the effectiveness of biomass expansion factors to estimate stand biomass," presented at the International Conference on Modeling Forest Production Vienna, Austria, 2004.

8. Z. Somogyi, M. Teobaldelli, S. Federici, G. Matteucci, V. Pagliari, G. Grassi, et al. (2008, Allometric biomass and carbon factors database. iForest 1, 107-113. Available: http://www.sisef.it/-iforest/

9. Z. Somogyi, M. Teobaldelli, S. Federici, G. Seufert, G. Matteucci, and V. Pagliari. The Allometric Biomass and Carbon Factors Database [Online]. Available: http://aloludata.jrc.it/data_fs.cfm

10. M. Teobaldelli. The Biomass Compartments Database. [Online]. Available: http://afoludata.jrc.it/DS_Free/AF_Bio.cfm

11. M. Teobaldelli, Z. Somogyi, M. Migiliavacca, and V. A. Usoltsev, "Generalized functions of biomass expansion factors for conifers and broadleaved by stand age, growing stock and site index," Forest Ecology and Management, vol. 257, pp. 1004-1013, 2009.

12. R. C. Dowell, D. Gibbins, J. L. Rhoads, and S. G. Pallardy, "Biomass production physiology and soil carbon dynamics in short-rotation-grown Populus deltoides and P. deltoides x P. nigra hybrids," Forest Ecology and Management, vol. 257, pp. 134-142, 2009.

13. P. E. Heilman and X. Fu-Gaung, "Influence of nitrogen on growth and productivity of short-rotation Populus trichocarpa x Populus deltoides hybrids,” Candian Journal of Forest Research, vol. 23, pp. 1863-1869, 1993.

14. P. E. Heilman, G. Ekuan, and D. B. Fogle, "Above- and below-ground biomass and fine roots of fouryear-old hybrids of Populus trichocarpa x P. deltoides and parental species in short rotation culture," Canadian Journal of Forest Research, vol. 24, pp. 1186-1192, 1994.

15. R. J. Ceulemans, G. E. Scarascia-Mugnozza, B. M. Wiard, J. H. Braatne, T. M. Hinckley, R. F. Stettler, et al., "Production physiology and morphology of Populus species and their hybrids grown under short rotation. I. Clonal comparisons of 4-year growth and phenology,” Canadian Journal of Forest Research, vol. 22, pp. 1937-1948, 1992.

16. R. F. Kopp, L. P. Abrahamson, E. H. White, K. F. Burns, and C. A. Nowak, "Cutting cycle and spacing effects on biomass production by a willow clone in New York," Biomass and Bioenergy, vol. 12, pp. 313-319, 1997. 
17. H. G. Adegbidi, T. A. Volk, E. H. White, L. P. Abrahamson, R. D. Briggs, and D. H. Bickelhaupt, "Biomass and nutrient removal by willow clones in experimental bioenergy plantations in New York State,” Biomass \& Bioenergy, vol. 20, pp. 399-411, 2001.

18. R. F. Kopp, L. P. Abrahamson, E. H. White, T. A. Volk, C. A. Nowak, and R. C. Fillhart, "Willow biomass production during ten successive annual harvests," Biomass and Bioenergy, vol. 20, pp. 1-7, 2001.

19. C. H. Strauss, S. C. Grado, P. R. Blankenhorn, and T. W. Bowersox, "Cost parameters affecting multiple rotation SRIC biomass systems,” Applied Biochemistry and Biotechnology, vol. 24-25, pp. 721-733, 1990a.

20. H. G. Adegbidi, R. D. Briggs, T. A. Volk, E. H. White, and L. P. Abrahamson, "Effect of organic amendments and slow-release nitrogen fertilizer on willow biomass production and soil chemical characteristics,” Biomass \& Bioenergy, vol. 25, pp. 389-398, 2003.

21. M. Labrecque and T. I. Teodorescu, "Field performance and biomass production of 12 willow and poplar clones in short-rotation coppice in southern Quebec (Canada).” Biomass and Bioenergy, vol. 29, pp. 1-9, 2005.

22. T. W. Bowersox and W. W. Ward, "Growth and yield of close-spaced, young hybrid poplars," Forest Science, vol. 22, pp. 449-454, 1976.

23. J. Zavitkovski, J. G. Isebrands, and D. H. Dawson, "Productivity and utilization potential of shortrotation Populus in the Lake States,” presented at the Proceedings: Symposium on Eastern Cottonwood and Related Species, Baton Rouge, Louisiana, 1976.

24. T. F. Strong and E. A. Hansen, "Hybrid poplar spacing/productivity relations in short rotation intensive culture plantations,” Biomass and Bioenergy, vol. 4, pp. 255-261, 1993.

25. T. F. Strong, "Rotation Length and Repeated Harvesting Influence Populus Coppice Production," U.S. Forest Service, North Central Forest Experiment Station, Duluth, Minnesota NC-350, 1989.

26. D. A. Netzer, D. N. Tolsted, M. E. Ostry, J. G. Isebrands, D. E. Riemenschneider, and K. T. Ward, "Growth, Yield, and Disease Resistance of 7-12 Year Old Poplar Clones in the North Central United States,” USDA Forest Service, North Central Experiment Station, St. Paul, MN, General Technical Report GTR-NC-229, 2002.

27. W. A. Geyer, "Growth, yield, and woody biomass characteristics of seven short-rotation hardwoods," Wood Science, vol. 13, pp. 209-215, 1981.

28. W. A. Geyer, "Biomass yield potential of short-rotation hardwoods in the Great Plains," Biomass, vol. 20, pp. 167-175, 1989.

29. R. S. Zalesny, R. B. Hall, J. A. Zalesny, B. G. McMahon, W. E. Berguson, and G. R. Stanoz, "Biomass and genotype $\mathrm{x}$ environment interactions of Populus energy crops in the Midwestern United States,” Bioenergy Research, vol. 2, pp. 106-102, 2009.

30. D. E. Riemenschneider, W. E. Berguson, D. I. Dickman, R. B. Hall, J. G. Isebrands, C. A. Mohn, et al., "Poplar breeding and testing strategies in the north-central U.S.: Demonstration of potential yield and consideration of future research needs.," The Forestry Chronicle, vol. 77, pp. 246-253, 2001.

31. D. R. Coyle, E. R. Hart, J. D. McMillin, L. C. Rule, and R. B. Hall, "Effects of repeated cottonwood leaf beetle defoliation on Populus growth and economic value over an 8-year harvest rotation," Forest Ecology and Management, vol. 255, pp. 3365-3373, 2008.

32. D. S. Debell, G. W. Clendenen, and J. C. Zasada, "Growing Populus biomass: comparison of woodgrass versus wider-spaced short-rotation systems,” Biomass and Bioenergy, vol. 4, pp. 305-313, 1993.

33. P. E. Heilman and R. F. Stettler, "Genetic variation and productivity of Populus trichocarpa and it's hybrids. II, Biomass Production in a 4-year plantation.," Canadian Journal of Forest Research, vol. 15, pp. 384-388, 1985.

34. P. E. Heilman and R. F. Stettler, "Genetic variation and productivity of Populus trichocarpa and its hybrids. IV. Performance in short-rotation coppice,” Canadian Journal of Forest Research, vol. 20, pp. 1257-1264, 1990. 
35. J. C. Weber, R. F. Stettler, and P. E. Heilman, "Genetic variation and productivity of Populus trichocarpa and its hybrids. I. Morphology and phenology of 50 native clones," Canadian Journal of Forest Research, vol. 15, pp. 376-383, 1985.

36. D. S. DeBell, G. W. Clendenen, C. A. Harrington, and J. C. Zasada, “Tree growth and stand development in short-rotation Populus plantings: 7-year results for two clones at three spacings,” Biomass and Bioenergy, vol. 11, pp. 253-269, 1996.

37. P. E. Heilman and D. V. Peabody Jr., "Effect of harvest cycle and spacing on productivity of black cottonwood in intensive culture,” Canadian Journal of Forest Research, vol. 11, pp. 118-123, 1981.

38. T. M. Williams and C. A. Gresham, "Biomass accumulation in rapidly growing loblolly pine and sweetgum,” Biomass and Bioenergy, vol. 30, pp. 370-377, 2006.

39. W. R. Cobb, R. E. Will, R. F. Daniels, and M. A. Jacobson, "Aboveground biomass and nitrogen in four short-rotation woody crop species growing with different water and nutrient availabilities," Forest Ecology and Management, vol. 255, pp. 4032-4039, 2008.

40. H. Van Miegroet, R. J. Norby, and T. J. Tschaplinski, "Nitrogen fertilization strategies in a shortrotation sycamore plantation,” Forest Ecology and Management, vol. 64, pp. 13-24, 1994.

41. A. A. Davis and C. C. Trettin, "Sycamore and sweetgum plantation productivity on former agricultural land in South Carolina,” Biomass and bioenergy, vol. 30, pp. 769-777, 2006.D. L.

42. Rockwood, C. W. Comer, D. R. Dippon, and J. B. Huffman, "Woody Biomass Production Options for Florida,” Agricultural Experiment Station Institute of Food and Agriculture Sciences (IFAS), University of Florida, Gainesville, Florida Bulletin 865, 1985.

43. S. J. Torreano and D. J. Frederick, "Influence of site condition, fertilization and spacing on short rotation hardwood coppice and seedling yields,” Biomass, vol. 16, pp. 183-198, 1988.

44. B. E. Roth, E. J. Jokela, T. A. Martin, D. A. Huber, and T. L. White, "Genotype $\times$ environment interactions in selected loblolly and slash pine plantations in the Southeastern United States," Forest Ecology and Management, vol. 238, pp. 175-188, 2007.

45. E. J. Jokela and T. A. Martin, "Effects of ontogeny and soil nutrient supply on production, allocation, and leaf area efficiency in loblolly and slash pine stands," Candian Journal of Forest Research, vol. 30, pp. 1511-1524, 2000. 

APPENDIX A. CONVERSION FACTORS 



\section{APPENDIX A. CONVERSION FACTORS}

\section{A.1 METRIC TO ENGLISH UNITS}

\begin{tabular}{lcl}
\hline \multicolumn{1}{c}{ Multiply } & by & \multicolumn{1}{c}{ To Obtain } \\
\hline & Mass & \\
grams (gm) & 0.0353 & ounces (oz) \\
grams (gm) & 0.0022 & pounds (lb) \\
kilograms (kg) & 2.2046 & pounds lb) \\
kilograms (kg) & 2205 & pounds (lb) \\
kilograms (kg) & 0.0011 & tons, US or short (t) \\
megagrams (Mg) or metric tons or tonne $(\mathrm{t})^{a}$ & 1.1020 & tons, US or short (t) \\
megagrams $(\mathrm{Mg})$ or metric tons or tonne $(\mathrm{t})^{a}$ & 0.9842 & tons, Imperial or long (tl) \\
\hline & Area & \\
\hline hectares (ha) & 2.4710 & acres (ac) \\
hectares (ha) & 0.0039 & square miles $\left(\mathrm{mi}^{2}\right)$ \\
square kilometers $\left(\mathrm{km}^{2}\right)^{b}$ & 247.10 & acres (ac) \\
square kilometers $\left(\mathrm{km}^{2}\right)$ & 0.3861 & square mile $\left(\mathrm{mi}^{2}\right)$ \\
square meters $\left(\mathrm{m}^{2}\right)$ & 1.1960 & square yards $\left(\mathrm{yd}^{2}\right)$ \\
square meters $\left(\mathrm{m}^{2}\right)$ & 10.7639 & square feet $\left(\mathrm{ft}^{2}\right)$ \\
square decimeter $\left(\mathrm{dm}^{2}\right)$ & 15.5000 & square inches $\left(\mathrm{in}^{2}\right)$ \\
square centimeters $\left(\mathrm{cm}^{2}\right)$ & 0.1550 & square inches $\left(\mathrm{in}^{2}\right)$ \\
square millimeters $\left(\mathrm{mm}^{2}\right)$ & 0.0020 & square inches $\left(\mathrm{in}^{2}\right)$ \\
\hline
\end{tabular}

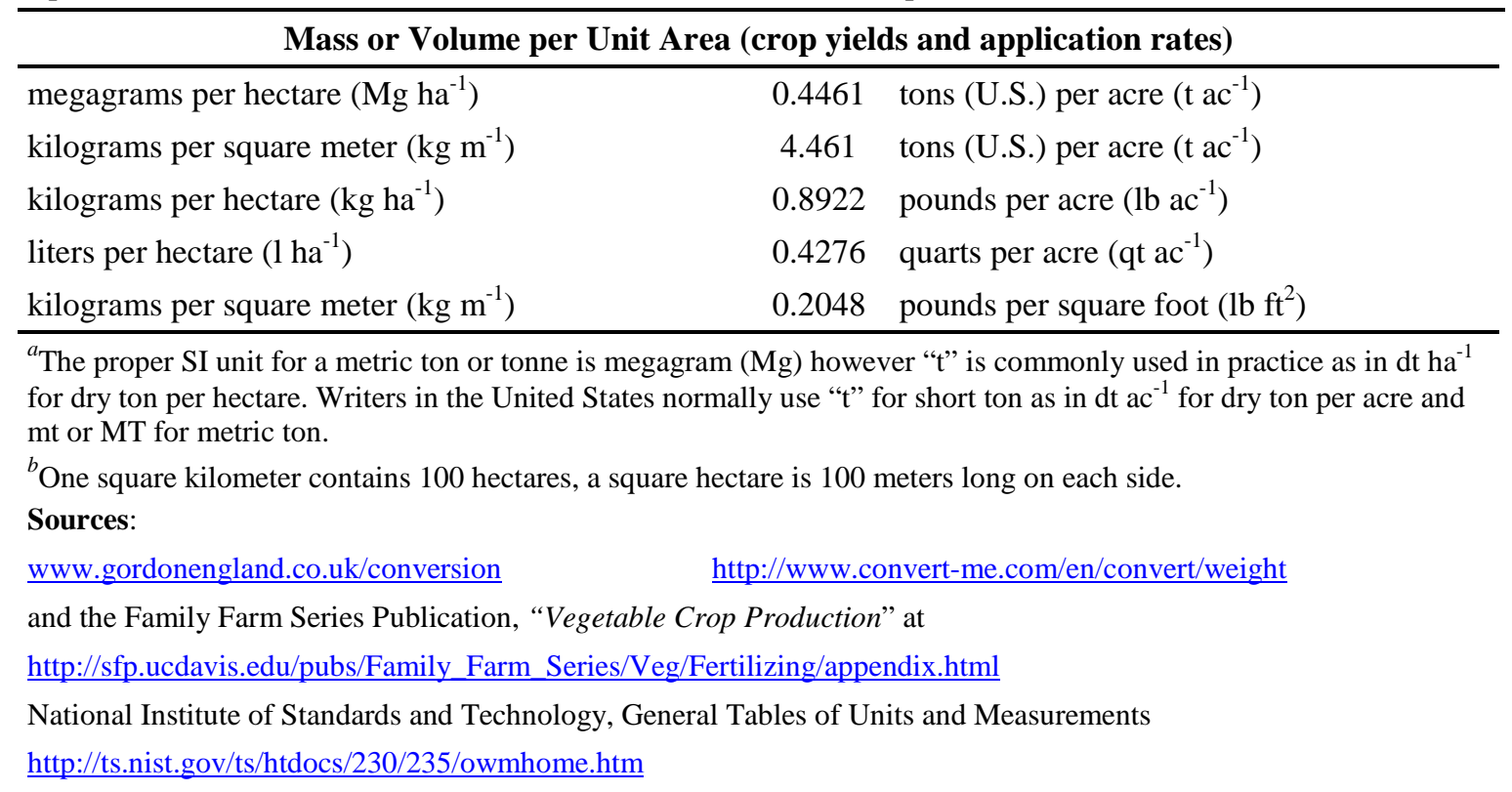




\section{A.2 ENGLISH TO METRIC UNITS}

\begin{tabular}{|c|c|c|}
\hline Multiply & by & To Obtain \\
\hline \multicolumn{3}{|c|}{ Mass } \\
\hline ounces (oz) & 28.3495 & grams (gm) \\
\hline pounds (lb) & 0.4536 & kilograms (kg) \\
\hline pounds (lb) & 453.6 & grams (gm) \\
\hline tons, US or short, (t) & 907.2 & kilograms (kg) \\
\hline tons, US or short (t) & 0.9072 & megagrams (Mg) or metric tons \\
\hline tons, Imperial or long $(\mathrm{tl})^{a}$ & 1016 & kilograms (kg) \\
\hline tons, Imperial or long (tl) ${ }^{a}$ & 1.016 & megagrams (Mg) or metric tons \\
\hline \multicolumn{3}{|c|}{ Area } \\
\hline acres $(\mathrm{ac})^{b}$ & 0.4047 & hectares (ha) \\
\hline square mile $\left(\mathrm{mi}^{2}\right)$ & 258.9990 & hectares (ha) \\
\hline square mile $\left(\mathrm{mi}^{2}\right)$ & 2.5900 & square kilometers $\left(\mathrm{km}^{2}\right)$ \\
\hline square yards $\left(\mathrm{yd}^{2}\right)$ & 0.8361 & square meters $\left(\mathrm{m}^{2}\right)$ \\
\hline square feet $\left(\mathrm{ft}^{2}\right)$ & 0.0929 & square meters $\left(\mathrm{m}^{2}\right)$ \\
\hline square inches $\left(\mathrm{in}^{2}\right)$ & 6.4516 & square centimeters $\left(\mathrm{cm}^{2}\right)$ \\
\hline square feet $\left(\mathrm{ft}^{2}\right)$ & 929.03 & square centimeters $\left(\mathrm{cm}^{2}\right)$ \\
\hline \multicolumn{3}{|c|}{ Mass or Volume per Unit Area (crop yields and application rates) } \\
\hline tons (U.S.) per acre $\left(\mathrm{t} \mathrm{ac}^{-1}\right)$ & 2.2417 megag & rams per hectare $\left(\mathrm{Mg} \mathrm{ha}^{-1}\right)$ \\
\hline tons (U.S.) per acre $\left(\mathrm{t} \mathrm{ac}^{-1}\right)$ & 0.2241 kilogra & ams per square meter $\left(\mathrm{kg} \mathrm{m}^{-1}\right)$ \\
\hline pounds per acre $\left(\mathrm{lb} \mathrm{ac}^{-1}\right)$ & 1.121 kilogra & ams per hectare $\left(\mathrm{kg} \mathrm{ha}^{-1}\right)$ \\
\hline quarts per acre (qt ac $\left.{ }^{-1}\right)$ & 2.338 liters $\mathrm{p}$ & eer hectare $\left(1 \mathrm{ha}^{-1}\right)$ \\
\hline pounds per square foot $\left(\mathrm{lb} \mathrm{ft}^{2}\right)$ & 4.8824 kilogra & ams per square meter $\left(\mathrm{kg} \mathrm{m}^{-1}\right)$ \\
\hline
\end{tabular}

${ }^{a}$ US tons equal 2,000 lb; imperial or long tons equal 2,240 lb.

${ }^{b}$ An acre contains 43,560 square feet. If the acre is square, the length of a side is equal to the square root of 43,560 or about 208.71 feet. One square mile equals 640 acres; one acre equals 0.0015625 square miles.

Sources:

www.gordonengland.co.uk/conversion $\quad$ http://www.convert-me.com/en/convert/weight

and the Family Farm Series Publication, "Vegetable Crop Production" at

http://sfp.ucdavis.edu/pubs/Family_Farm_Series/Veg/Fertilizing/appendix.html

National Institute of Standards and Technology, General Tables of Units and Measurements

http://ts.nist.gov/ts/htdocs/230/235/owmhome.htm 
APPENDIX B. NUTRIENT APPLICATION RATE STANDARDIZATION 



\section{APPENDIX B. NUTRIENT APPLICATION RATE STANDARDIZATION}

Step 1: Convert English fertilizer application rates to metric application rates

$$
\mathrm{lb} \mathrm{ac}^{-1} * 1.12=\mathrm{kg} \mathrm{ha}^{-1}
$$

Step 2: Standardize fertilizer level application rates across all experiments in database. This required determining the mass weight of elemental $\mathrm{N}, \mathrm{P}$, and $\mathrm{K}$ applied based on types of fertilizers used. The factors used were as follows:

$\mathrm{NH}_{4} \mathrm{NO}_{3}$ (ammonium nitrate) $=35 \% \mathrm{~N}$ by mass

NPK $(10,10,10)=10 \%$ of total weight for nitrogen, phosphate $\left(\mathrm{P}_{2} \mathrm{O}_{5}\right)$ and potash $\left(\mathrm{K}_{2} \mathrm{O}\right)$.

$\mathrm{NH}_{4} \mathrm{NO}_{3}$ (ammonium nitrate) $=35 \% \mathrm{~N}$ by mass

$\mathrm{P}_{2} \mathrm{O}_{5}$ consists of $57.4 \%$ oxygen and $43.6 \%$ elemental phosphorus

$\mathrm{K}_{2} \mathrm{O}$ consists of $17 \%$ oxygen and $83 \%$ elemental potassium

DAP (diammonium phosphate) $=18 \%$ Ammoniacal nitrogen and $46 \%$ available $\mathrm{P}_{2} \mathrm{O}_{5}$

$\mathrm{P}_{2} 0_{5} \times 0.4367=$ elemental phosphorus by mass

Thus available elemental $\mathrm{P}=20 \%$ of DAP

TSP (triple super phosphate) $=45 \%$ elemental phosphate by mass .

KCL (potassium chloride) $=60 \%$ elemental potassium by mass

Urea $=46 \%$ elemental nitrogen by mass

Information source: http://www.ncagr.gov/agronomi/obt419.htm.

Table B.1. Example of conversions when multiple types of fertilizers applied in some years (example is from Borders, Will et al. (2004) ${ }^{3}$ )

\begin{tabular}{|l|l|l|l|l|l|l|l|l|}
\hline Year & $\begin{array}{l}\text { NH4NO3 } \\
\mathbf{k g ~ h a}^{-1}\end{array}$ & $\begin{array}{c}\text { NPK } \\
(\mathbf{1 0 - 1 0 - 1 0})\end{array}$ & $\mathbf{D A P}$ & $\mathbf{T S P}$ & $\mathbf{K C L}$ & $\begin{array}{c}\mathbf{N}^{\mathbf{a}} \\
\mathbf{k g ~ h a}^{-\mathbf{1}}\end{array}$ & $\begin{array}{c}\mathbf{P}^{\mathbf{a}} \mathbf{k g ~ h a}^{-\mathbf{1}} \\
\mathbf{k g ~ h a}^{\mathbf{a}}\end{array}$ \\
\hline 1 & 56 & & 280 & & 112 & 70 & 129 & 67.2 \\
\hline 2 & 56 & & 280 & & 112 & 70 & 129 & 67.2 \\
\hline 3 & 150 & & & & & 52.5 & 0 & 0 \\
\hline 4 & 150 & & & & & 52.5 & 0 & 0 \\
\hline 5 & 150 & & & & & 52.5 & 0 & 0 \\
\hline 6 & 150 & & & & & 52.5 & 0 & 0 \\
\hline 7 & 150 & & & & & 52.5 & 0 & 0 \\
\hline 8 & 150 & & & & & 52.5 & 0 & 0 \\
\hline 9 & 150 & & & & & 52.5 & 0 & 0 \\
\hline 10 & 336 & & & 140 & & 117.6 & 63 & 0 \\
\hline 11 & 168 & 560 & & & & 114.8 & 56 & 56 \\
\hline 12 & 336 & & & & & 117.6 & 0 & 0 \\
\hline 13 & 336 & & & & & 117.6 & 0 & 0 \\
\hline 14 & 336 & & & & & 117.6 & 0 & 0 \\
\hline 15 & 336 & & & & & 117.6 & 0 & 0 \\
\hline
\end{tabular}

${ }^{\mathrm{a}}$ The mass weight of elemental N, P, and K values in the fertilizer formulations given in columns 2-6 are provided below for each growth year. Example calculations for elemental NPK kg ha-1 mass weight values for year 1 are as follows: $\mathrm{N}=(56 \times .35)+(280 \times .18)=70, \mathrm{P}=(280 \times .46) \times 0.4367=129, \mathrm{~K}=(112 \times 0.6)=67.2$. 



\section{APPENDIX C. EXPLANATION OF WHY SPACING AND DENSITY VALUES WERE NOT TOTALLY STANDARDIZED ACROSS EXPERIMENTS}





\section{APPENDIX C. EXPLANATION OF WHY SPACING AND DENSITY VALUES WERE NOT TOTALLY STANDARDIZED ACROSS EXPERIMENTS.}

Spacing and density values in the dataset require some explanation. The "spacing” values are normally reported as stated by the authors as "row $\mathrm{x}$ between row" spacing as metric values. The spacing values always represent the planted spacing of the trial. Those values had to be estimated when the authors provided only an approximated planting density number. If the authors reported spacing in English values, those were converted to metric values with two decimal points in the database (see table below). In most publications, however, the authors themselves had converted English unit spacing to metric unit spacing at various levels of accuracy. Sometimes it was easy to discern whether the original spacing had been in English units (such as when the metric units contained one or two decimal places), whereas at other times, it was not so easy to discern (such as when the authors used very approximate conversions). In very recent publications it appeared more likely that the original row and between-row distances had actually been measured in metric units (reflected by use of whole and half meter units).

Difficulties in standardizing tree density values resulted from the following factors.

1. Some investigators approximated spacing and density values much more loosely than others.

2. Some authors described a given experiment in approximated English units in one publication but in approximated metric units in another publication - thus it was difficult to be sure of the spacing at planting.

3. Some authors reported initial density values that did not agree (according to our calculations) with the reported spacing values, but because the initial density values were used in tables and graphs the Woody Crop Yield Potential (WCYP) Database retained those published values.

4. Imprecise or rounded spacing values converted to density values are only approximations.

Because there are several different approaches to approximating planted tree density per unit area, the WCYP dataset values for density are rarely exactly the same as the published density values. Below are some of the rules followed in determining the numbers entered in the WCYP database for spacing and density.

1. Planting density numbers were based directly on the author's statement of density only when planting spacing was not given or when the stated density was used in graphics or tables as a basis for showing density changes (mortality) (e.g., Samuelson et al., 2008).

2. When English unit spacing values were provided (e.g., $8 \mathrm{ft} \times 8 \mathrm{ft}$ ), the default calculation was to first calculate density based on English spacing units (e.g., 681 trees $\mathrm{ac}^{-1}$ ) then convert that value to a metric density $\left(681\right.$ trees ac $\left.\mathrm{ac}^{-1} \times 2.471 \mathrm{ac} \mathrm{ha}^{-1}\right)$. The resultant value of 1,682 trees ha ${ }^{-1}$ would be used in the WCYP database.

3. When metric unit spacing values were provided (e.g., $2.4 \times 2.4 \mathrm{~m}$ ) and no density values were provided by the author, then the default calculation approach was to use the given metric numbers as the basis for calculating trees per hectare (which at $2.4 \times 2.4 \mathrm{~m}$ results in a calculated estimate of 1,736 trees $\mathrm{ha}^{-1}$ ).

4. When it seemed obvious that the author's spacing values (e.g., $2.4 \times 2.4)$ were converted from English unit spacing values, then the WCYP database density value tree density was calculated from the presumed original English units (most likely $8 \mathrm{ft} \times 8 \mathrm{ft}$ in this case), thus resulting in the estimate 
of 1,682 trees/ha in example 2). This approach results in an estimated decrease of 54 trees/ha or about $3.1 \%$ less than the value calculated based on $2.4 \times 2.4 \mathrm{~m}$ spacing.

5. When it was not possible to know whether metric or English units were used to determine planting distances, or when the authors used the exact English to metric conversion to two significant digits, then the calculated density in the WCYP database was based on the published metric unit spacing.

The differences in calculated numbers of trees per unit area are relatively minor and probably not worth getting very concerned about, but it should be noted that unless conversions are performed carefully, they do contribute to errors in overall yields per unit area. In the example given in this paragraph the authors could be overestimating yields by about 3\% if they planted using English units but estimated yields using approximated metric values and by also scaling from average weight of a single tree to total weight of wood within a hectare of land.

It is worth noting that a much greater error in yield estimates is potentially being made by authors if mortality of the trees is not carefully assessed and incorporated into their yield assessments. Data on the survival (or mortality) of trees was reasonably well reported in this database though survival percentages were usually only reported for the end of the experimental observation period. In some cases, either survival (or mortality) or the change in density as a function of age was reported in graphs or tables in the publications evaluated. The Density (trees ha ${ }^{-1}$ ) column in the Growth Pattern worksheet in the WCYP database gives the initial planting density during all years of the experimental trial with an exception for one trial where coppice stem density was reported (but not the stump density). This exception is flagged by a comment box associated with the density values. The adjacent column (Survival) provides the percentage changes in survival over time (if published).

Decisions on how to report density values were just one of the many judgments required during the compilation of the WCYP dataset. The decisions made by this author were based on an in-depth knowledge of the woody crop experimental trials and assumptions about how the database might be used.

\section{REFERENCE}

L. J. Samuelson, J. Butnor, C. Maier, T. A. Stokes, K. Johnsen, and M. Kane, “Growth and physiology of loblolly pine in response to long-term resource management: defining growth potential in the southern United States,” Canadian Journal of Forest Research, vol. 38, pp. 721-732, 2008. 
